\title{
Flavor and flavor chemistry differences among milks processed by high-temperature, short-time pasteurization or ultra-pasteurization
}

\author{
Y. Jo, ${ }^{*}$ D. M. Benoist, ${ }^{*}$ D. M. Barbano, $†$ and M. A. Drake*1 \\ *Department of Food, Bioprocessing and Nutrition Sciences, Southeast Dairy Foods Research Center, North Carolina State University, \\ Raleigh 27695 \\ †Northeast Dairy Research Center, Department of Food Science, Cornell University, Ithaca, NY 14850
}

\section{ABSTRACT}

Typical high-temperature, short-time (HTST) pasteurization encompasses a lower heat treatment and shorter refrigerated shelf life compared with ultrapasteurization (UP) achieved by direct steam injection (DSI-UP) or indirect heat (IND-UP). A greater understanding of the effect of different heat treatments on flavor and flavor chemistry of milk is required to characterize, understand, and identify the sources of flavors. The objective of this study was to determine the differences in the flavor and volatile compound profiles of milk subjected to HTST, DSI-UP, or IND-UP using sensory and instrumental techniques. Raw skim and raw standardized $2 \%$ fat milks $(50 \mathrm{~L}$ each) were processed in triplicate and pasteurized at $78^{\circ} \mathrm{C}$ for 15 $\mathrm{s}$ (HTST) or $140^{\circ} \mathrm{C}$ for $2.3 \mathrm{~s}$ by DSI-UP or IND-UP. Milks were cooled and stored at $4^{\circ} \mathrm{C}$, then analyzed at $\mathrm{d}$ $0,3,7$, and 14 . Sensory attributes were determined using a trained panel, and aroma active compounds were evaluated by solid-phase micro-extraction or stir bar sorptive extraction followed by gas chromatographymass spectrometry, gas chromatography-olfactometry, and gas chromatography-triple quad mass spectrometry. The UP milks had distinct cooked and sulfur flavors compared with HTST milks. The HTST milks had less diversity in aroma active compounds compared with UP milks. Flavor intensity of all milks decreased by d 14 of storage. Aroma active compound profiles were affected by heat treatment and storage time in both skim and $2 \%$ milk. High-impact aroma active compounds were hydrogen sulfide, dimethyl trisulfide, and methional in DSI-UP and 2 and 3-methylbutanal, furfural, 2-heptanone, 2-acetyl-1-pyrroline, 2-aminoacetophenone, benzaldehyde, and dimethyl sulfide in IND-UP. These results provide a foundation knowledge of the effect of heat treatments on flavor development and differences in sensory quality of UP milks.

Received October 30, 2017.

Accepted January 3, 2018.

${ }^{1}$ Corresponding author: mdrake@ncsu.edu
Key words: fluid milk, ultra-pasteurization, flavor

\section{INTRODUCTION}

The flavor of dairy products is a critical parameter affecting consumer acceptance, shelf life, and other attributes (Kühn et al., 2006; Drake et al., 2007). For fluid milk, flavor is initially influenced by raw milk quality, such as microbial counts and heat-resistant enzymes present in milk (Barbano et al., 2006). When thermal treatment is employed to reduce or destroy the microbial load and enzyme activity to ensure safety and to increase shelf life, the flavor of the milk changes and differs from that of raw milk (Walstra et al., 1999). Typical milk processing in the United States involves HTST pasteurization (minimum of $72^{\circ} \mathrm{C}$ for $15 \mathrm{~s}$ ), providing approximately $3 \mathrm{wk}$ of shelf life (Boor, 2001). Ultra-pasteurization (UP) and UHT are also thermal treatments for extended shelf life of milk (Boor, 2001; Colahan-Sederstrom and Peterson, 2005; Lee et al., 2017). The thermal processing conditions for UP milk are defined as at or above $138^{\circ} \mathrm{C}\left(280^{\circ} \mathrm{F}\right)$ for at least 2 s (21 CFR 131.3, FDA, 2017), and this product generally has an extended shelf life under refrigerated conditions. The UHT milk has the same thermal process as for UP milk, but the milk is aseptically packaged to be shelf stable for at least 6 mo without refrigeration (Boor, 2001). Processing by UP can be operated with 2 continuous heating methods: (1) direct heating, which quickly heats the milk by direct steam injection (DSIUP), followed by vacuum cooling to remove water from the steam, and (2) indirect heating (IND-UP), which heats the milk by a tubular, scraped surface heat exchanger or plate-heat exchanger (Datta et al., 2002; Lee et al., 2017). The UP milk receives a significantly higher thermal load than HTST milk shown by thermal damage indicators, such as furosine and serum protein denaturation (Lee et al., 2017). Lee et al. (2017) reported that IND-UP milks had the highest furosine content, followed by DSI-UP, and HTST. In contrast, UP milks had more serum protein denaturation than HTST, but IND-UP was more severe than DSI-UP (Lyster et al., 
1971; Lee et al., 2017). Due to differences in heat time, temperature, and total heat load, the sensory profiles of DSI-UP, IND-UP, and HTST milks were all distinct (Lee et al., 2017).

The flavor of pasteurized milk is derived from various reactions during thermal processing or storage, which also affect color (Schamberger and Labuza, 2007). Key changes in flavor during thermal processing of milk are associated with Maillard reactions (Van Boekel, 1998; Colahan-Sederstrom and Peterson, 2005; Kokkinidou and Peterson, 2014; Troise et al., 2014), lipid degradation (Calvo and Hoz, 1992), and thermal denaturation of serum (whey) protein and other proteins in the milk fat globule membrane (Mehta, 1980). Lactose and amino groups in milk proteins undergo Maillard reactions during heat treatment, and this process generates a wide range of flavor compounds, such as Strecker aldehydes, sulfur- and nitrogen-containing compounds, maltol, and diacetyl (Calvo and Hoz, 1992; Van Boekel, 1998; Reineccius, 2006). Lipid degradation during thermal processing of milk induces $\beta$-oxidation of free fatty acids generating methyl ketones (Calvo and Hoz, 1992). $\beta$-Lactoglobulin in serum protein liberates volatile sulfur compounds by heat denaturation, which involves unfolding and exposure of reactive sulfides (Calvo and Hoz, 1992; Kühn et al., 2006).

Volatile compounds are the source of the aroma portion of food flavor, but only a small fraction of volatile compounds present in food are flavor active and contribute to flavor (Grosch, 2001). In classical flavor analysis, studies were focused on a single component of flavor and dependent on isolation of volatile compounds by different extraction methods using solvents (e.g., solvent extraction, and solvent-assisted flavor evaporation), or headspace extraction [e.g., dynamic headspace, solid phase microextraction (SPME), and stir-bar sorptive extraction (SBSE; Reineccius, 2006; Jeleń et al., 2012; Park and Drake, 2016]. These methods require time and several steps that often lead to the loss of volatile compounds (Vazquez-Landaverde et al., 2006). As flavor is a sensory perception, volatile compounds confirmed to be aroma active by olfactometry methods are more likely to be important compounds to flavor (Reineccius, 2006). More recently, new approaches include the combination of multiple techniques or detectors to obtain different classes of compounds in a single run (Vrhovsek et al., 2014). The SPME combined with GC-triple quadrupole mass spectrometry (GC-MS/MS) has been introduced to flavor studies of wine (Mattivi et al., 2011; Hjelmeland et al., 2012; Langen et al., 2013; Slabizki et al., 2016), single rice kernel (Hopfer et al., 2016), Perilla seed oils (Kwon et al., 2013), fruits (Vrhovsek et al., 2014), and tobacco
(Zhang et al., 2013) but has yet to be used in analyzing flavor compounds from milk.

The flavor of UP milk is distinct from HTST and has been characterized as having distinct sulfurous, cooked, cabbage, and caramelized notes (Colahan-Sederstrom and Peterson, 2005; Vazquez-Landaverde et al., 2006; Lee et al., 2017). These distinct flavors are a drawback of UP milk and are a barrier to US consumer acceptance (Perkins and Deeth, 2001; Lee et al., 2017). Lee at al. (2017) recently demonstrated that both adults and children preferred the flavor of HTST milk over DSI-UP or IND-UP milks. Previous studies on the flavor chemistry of UP milk (Colahan-Sederstrom and Peterson, 2005; Potineni and Peterson, 2005; Kokkinidou and Peterson, 2014) have been conducted with indirect heat treatment with limited information on actual UP parameters or without comparison to traditional HTST milks. More importantly, no previous study to our knowledge has directly compared the flavor chemistry of HTST versus UP with DSI and IND in relation to understanding the nature of the differences between direct and indirect heat treatment when starting from the same batch of raw milk. The objective of our study was to develop a comprehensive flavor chemistry profile of milk processed by HTST, DSI-UP, and IND-UP and to identify compounds responsible for the flavor differences of these milks (key aroma compounds, and odorants). A collaborative strategy of pilot plant processing and several sequential approaches for volatile compound extraction based on SPME and SBSE, in conjunction with GC-olfactometry (GC-O) followed by GC-MS, flame photometric detection (FPD), or MS/MS in conjunction with sensory analysis provided effective tools to characterize and compare the flavor profiles of milk.

\section{MATERIALS AND METHODS}

\section{Milk Preparation}

Two fat levels (skim and 2\%) and 3 different heat treatments (HTST, DSI-UP, and IND-UP) of milk were evaluated. Raw skim milk (200 L at $3.1 \%$ protein, $0.07 \%$ fat) and raw cream ( $45.4 \%$ fat) were obtained from the North Carolina State University dairy facility. The cream was separated from raw whole milk by a cold bowl separator (model 590, Separators Inc., Indianapolis, IN). Raw skim milk (100 L) was standardized to $2 \%$ fat milk with the raw cream. A microthermics EHVH pasteurization unit (Microthermics, Raleigh, NC) with a Microthermics Steam Injection Module, and a 2-stage homogenizer (model NS2006H, GEA Niro Soavi, Parma, Italy) was used for milk processing. Raw 
Table 1. Multiple reaction monitoring transition parameters for selected compounds for GC-triple quad-mass spectrometry (MS/MS) analytical conditions

\begin{tabular}{|c|c|c|c|c|c|c|c|c|c|c|}
\hline No. & Compound & $\begin{array}{l}\text { Precursor } \\
\text { ion }(m / z)\end{array}$ & \multicolumn{6}{|c|}{ Product ion } & \multicolumn{2}{|c|}{ Calibration curve } \\
\hline 1 & Hydrogen sulfide & 34 & 32 & 3 & & & & & $\mathrm{y}=15.077 \mathrm{x}$ & 0.99 \\
\hline 2 & Dimethyl sulfide & 62 & 47 & 4 & 46 & & & & $\mathrm{y}=0.0544 \mathrm{x}$ & 0.99 \\
\hline 3 & Carbon disulfide & 76 & 44 & 3 & 46 & 3 & & & $\mathrm{y}=15.305 \mathrm{x}$ & 0.99 \\
\hline 4 & 2-Butanone & 72 & 43 & 3 & 57 & 1 & & & $\mathrm{y}=0.0126 \mathrm{x}$ & 0.99 \\
\hline $\mathrm{ISTD}^{2} 1$ & Ethyl methyl sulfide & 76 & 61 & 2 & 48 & 2 & & & & \\
\hline 7 & 2-Methylbutanal & 86 & 58 & 3 & 57 & 10 & 44 & 10 & $\mathrm{y}=0.0544 \mathrm{x}$ & 0.95 \\
\hline 8 & Dimethyl disulfide & 94 & 79 & 10 & 64 & 15 & & & $\mathrm{y}=1.9237 \mathrm{x}$ & 0.99 \\
\hline 9 & Hexanal & 72 & 57 & 4 & 43 & 4 & & & $\mathrm{y}=0.0032 \mathrm{x}$ & 0.99 \\
\hline 10 & Dimethyl sulfoxide & 78 & 63 & 3 & 61 & 3 & & & $\mathrm{y}=202.26 \mathrm{x}$ & 0.99 \\
\hline 11 & Furfural & 96 & 39 & 15 & 40 & 15 & & & $\mathrm{y}=5.18 \mathrm{x}$ & 0.99 \\
\hline 12 & 2-Heptanone & 114 & 71 & 5 & & & & & $\mathrm{y}=0.001 \mathrm{x}$ & 0.98 \\
\hline 17 & 1-Octen-3-ol & 72 & 57 & 3 & 43 & 3 & & & $\mathrm{y}=0.2758 \mathrm{x}$ & 0.96 \\
\hline 18 & Butyric acid & 88 & 60 & 10 & 55 & 10 & & & $y=44.658 x$ & 0.98 \\
\hline 19 & Benzaldehyde & 106 & 77 & 10 & 51 & 10 & & & $\mathrm{y}=2.4113 \mathrm{x}$ & 0.98 \\
\hline 20 & Phenyl acetate & 136 & 94 & 10 & 66 & 20 & & & $\mathrm{y}=4.6309 \mathrm{x}$ & 0.97 \\
\hline 21 & Furaneol & 128 & 85 & 3 & 57 & 10 & & & $\mathrm{y}=37.128 \mathrm{x}$ & 0.99 \\
\hline 22 & Maltol & 126 & 71 & 15 & 97 & 10 & 55 & 15 & $\mathrm{y}=7.7084 \mathrm{x}$ & 0.96 \\
\hline 23 & 2-Acetyl-2-thiazoline & 129 & 60 & 5 & 101 & 5 & 87 & 5 & $\mathrm{y}=1.9929 \mathrm{x}$ & 0.98 \\
\hline 24 & Sotolon & 128 & 82 & 4 & 100 & 4 & 72 & 4 & $\mathrm{y}=26.029 \mathrm{x}$ & 0.97 \\
\hline 25 & 2-Aminoacetophenone & 135 & 120 & 15 & 92 & 20 & & & $\mathrm{y}=0.2525 \mathrm{x}$ & 0.98 \\
\hline 26 & $\delta$-Octalactone & 142 & 87 & 5 & 99 & 5 & 113 & 5 & $\mathrm{y}=6.7516 \mathrm{x}$ & 0.99 \\
\hline 27 & Skatole & 130 & 77 & 15 & 103 & 15 & & & $\mathrm{y}=2.9212 \mathrm{x}$ & 0.97 \\
\hline 28 & $\gamma$-Decalactone & 170 & 95 & 15 & 85 & 15 & 113 & 10 & $\mathrm{y}=9.6237 \mathrm{x}$ & 0.99 \\
\hline 29 & $\delta$-Decalactone & 152 & 97 & 3 & 84 & 3 & 109 & 3 & $y=9.6237 x$ & 0.99 \\
\hline
\end{tabular}

${ }^{1} \mathrm{CE}=$ collision energy.

${ }^{2}$ ISTD $=$ internal standard.

skim and raw $2 \%$ milks were processed by HTST, DSIUP, or IND-UP as described by Lee et al. (2017).

For HTST treatment, raw milks were preheated at $60^{\circ} \mathrm{C}$, homogenized and pasteurized at $78^{\circ} \mathrm{C}$ for $15 \mathrm{~s}$ at a flow rate of $2.0 \mathrm{~L} / \mathrm{min}$ before cooling to $10^{\circ} \mathrm{C}$. The DSI-UP milks were processed at a flow rate 1.2 $\mathrm{L} / \mathrm{min}$, preheated at $90^{\circ} \mathrm{C}$, and heated to $140^{\circ} \mathrm{C}$ for $2.3 \mathrm{~s}$ by direct culinary steam injection (model LG-30, Electro-Steam Generator Corp., Alexandria, VA) using a Microthermics Steam Injection Module. Then milks were cooled to $85^{\circ} \mathrm{C}$ by vacuum cooling to remove heat and water added as steam. The DSI-UP milks were then homogenized and cooled to $10^{\circ} \mathrm{C}$. For IND-UP, milks were preheated at $90^{\circ} \mathrm{C}$ and pasteurized at $140^{\circ} \mathrm{C}$ for $2.3 \mathrm{~s}$ at a $1.3 \mathrm{~L} / \mathrm{min}$ flow rate. Milks were cooled to $85^{\circ} \mathrm{C}$ before homogenization and then cooled to $10^{\circ} \mathrm{C}$. All milks were packaged in light-shielded, half-gallon high-density polyethylene containers (Upstate Niagara Cooperative Inc., Buffalo, NY), stored at $4^{\circ} \mathrm{C}$, and sampled at d $0,3,7$, and 14 for analyses. The experiment was replicated in triplicate.

\section{Chemical Standards}

Chemical standards (no. 1-12, 14-29, and internal standards 1 and 2; Table 1) were purchased from Sigma-Aldrich (St. Louis, MO). A standard (no. 13; Table 1) was obtained from BOC Sciences (Shirley, NY).

\section{Proximate Analysis}

Fat, protein, and solids concentrations (g/100 $\mathrm{g}$ of milk) of milks were measured by a Fourier-transform mid-infrared milk analyzer (LactoScope FTIR, Delta Instruments BC, Drachten, the Netherlands) to verify formulation and for process control. Pre-calibration (Lynch et al., 2006) and calibration (Kaylegian et al., 2006) of the mid-infrared milk analyzer with modified milks were performed as described. Milk pasteurization was confirmed by alkaline phosphatase test (AOAC method 946.03, AOAC International, 2000; Phos-kit, Weber Scientific, Hamilton, NJ). Fat particle size was measured using a Mastersizer 2000 (Malvern Instru- 
ment Ltd., Malvern, UK) as described by Di Marzo et al. (2016) to confirm appropriate homogenization.

\section{Descriptive Sensory Analysis}

Sensory analysis was conducted in accordance with the North Carolina State University Institutional Review Board for the Protection of Human Subjects in Research regulations. Sensory properties of milk were evaluated by 6 trained panelists at d 3, 7, and 14. Each panelist ( 4 females, 2 males, ages 21 to $55 \mathrm{yr}$ ) had a minimum of $80 \mathrm{~h}$ of experience evaluating flavor and texture attributes of foods using the spectrum method (Meilgaard et al., 2007), and at least $40 \mathrm{~h}$ of experience with evaluation of fluid milk sensory attributes using an established sensory language (Croissant et al., 2007; Lee et al., 2017; McCarthy et al., 2017). Milks (30 mL) were dispensed into 59-mL soufflé cups with lids (Dart Container Corp., Mason, MI) with random 3-digit blinding codes. Samples were prepared with overhead lights off to prevent light oxidation, and tempered to $10^{\circ} \mathrm{C}$. Each panelist evaluated each milk in duplicate using Compusense Cloud (Compusense, Guelph, Canada).

\section{Extraction of Volatile Compounds}

Headspace-SPME-GC-MS. Volatile compounds in milks were evaluated at d $0,3,7$, and 14 . All injections were made on an Agilent 7820 GC with 5975 MSD (Agilent Technologies Inc., Santa Clara, CA) with a ZB- $5 \mathrm{~ms}(30 \mathrm{~m}$ length $\times 0.25 \mathrm{~mm}$ i.d. $\times 0.25$ $\mu \mathrm{m}$ film thickness; Phenomenex, Torrance, CA) column. Sample introduction was accomplished using a CTC Analytics CombiPal Autosampler (CTC Analytics, Zwingen, Switzerland). Analytical conditions for GC-MS were adapted from Vazquez-Landaverde et al. (2006). Five milliliters of milk along with $20 \mu \mathrm{L}$ of internal standard (2-methyl-3-heptanone in ethyl ether at $81 \mathrm{mg} / \mathrm{kg}$ ) was added to $20-\mathrm{mL}$ SPME autosampler vials with steel screw tops containing silicone septa faced in Teflon (Microliter Analytical, Suwanee, GA) in triplicate. Vials were equilibrated for $25 \mathrm{~min}$ at $35^{\circ} \mathrm{C}$ with $4 \mathrm{~s}$ of pulsed $250 \mathrm{rpm}$ agitation. A single 50/30 $\mu \mathrm{m}$ divinylbenzene/carboxen/polydimethylsiloxane (DVB/CAR/PDMS; Supelco, Bellefonte, PA) 1-cm fiber was used for all analysis. The SPME fiber was exposed to the samples for $40 \mathrm{~min}$ at a depth of 31 $\mathrm{mm}$. The fiber was retracted and injected at $50 \mathrm{~mm}$ in the $\mathrm{GC}$ inlet for $5 \mathrm{~min}$. The GC oven was initially held at $35^{\circ} \mathrm{C}$ for $3 \mathrm{~min}$ with a gradual increase of $10^{\circ} \mathrm{C} /$ min to $150^{\circ} \mathrm{C}$ and held for $1 \mathrm{~min}$ then raised at a rate of $20^{\circ} \mathrm{C} / \mathrm{min}$ to $250^{\circ} \mathrm{C}$ and maintained for $5 \mathrm{~min}$. The SPME fiber was introduced into the inlet with splitless mode at $250^{\circ} \mathrm{C}(0.75$ min valve delay $)$. All analyses were performed at a constant flow rate of $1 \mathrm{~mL} / \mathrm{min}$ with helium. Scanning parameters were set from 30 to $350 \mathrm{~m} / \mathrm{z}$ to identify compounds of interest. The MS transfer line was maintained at $250^{\circ} \mathrm{C}$ with the quad at $150^{\circ} \mathrm{C}$ and source at $230^{\circ} \mathrm{C}$.

Headspace-SPME-GC-O . The SPME followed by $\mathrm{GC}-\mathrm{O}$ for aroma active compound characterization was conducted on all milks (HTST, DSI-UP, and INDUP) at d 0, 3, 7, and 14. All injections were made on an Agilent $6850 \mathrm{GC}$ (Agilent Technologies Inc.) with ZB-5 and ZB-Wax $(30 \mathrm{~m}$ length $\times 0.25 \mathrm{~mm}$ i.d. $\times$ $0.25 \mu \mathrm{m}$ film thickness; Phenomenex) columns. Sample introduction was accomplished using a manual SPME holder (Supelco) equipped with an DVB/CAR/PDMS (Supelco) fiber. Ten milliliters of milk was added to 40$\mathrm{mL}$ amber vials. Vials were equilibrated for $30 \mathrm{~min}$ at $35^{\circ} \mathrm{C}$, and the SPME fiber was exposed to the samples for $30 \mathrm{~min}$ at a depth of $20 \mathrm{~mm}$. The fiber was retracted and injected at $30 \mathrm{~mm}$ in the $\mathrm{GC}$ inlet for $5 \mathrm{~min}$. The $\mathrm{GC}$ oven was initially held at $35^{\circ} \mathrm{C}$ for 3 min with a gradual increase of $10^{\circ} \mathrm{C} / \mathrm{min}$ to $150^{\circ} \mathrm{C}$, then raised at a rate of $30^{\circ} \mathrm{C} / \mathrm{min}$ to $250^{\circ} \mathrm{C}$ and maintained for $10 \mathrm{~min}$. All analyses were performed at a constant flow rate of $2.0 \mathrm{~mL} / \mathrm{min}$ with helium. Effluent was split 1:1 between the flame ionization detector and sniffing port using deactivated fused-silica capillaries $(1 \mathrm{~m}$ length $\times 0.25$ $\mathrm{mm}$ i.d.; Phenomenex). The flame ionization detector sniffing port was held at a temperature of $300^{\circ} \mathrm{C}$, and the port was supplied with humidified air at $30 \mathrm{~mL} /$ min. Each sample was evaluated on each column by at least 2 highly experienced sniffers (each with $>50 \mathrm{~h}$ previous experience with GC-O) who recorded aroma character, perceived intensity, and retention time.

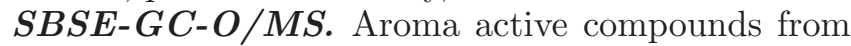
milks were also evaluated by SBSE-GC-O/MS. All injections were made on an Agilent 7890B GC with 5977 MSD attached with a ZB- $5 \mathrm{~ms}(30 \mathrm{~m}$ length $\times 0.25$ $\mathrm{mm}$ i.d. $\times 0.25 \mu \mathrm{m}$ film thickness; Phenomenex) column and an Olfactory Detection Port-3 (ODP-3) unit (Gerstel Inc., Mülheim an der Ruhr, Germany). Sample introduction was accomplished using a CTC Analytics CombiPal Autosampler (CTC Analytics). Thermal desorption was performed by a thermal desorption unit (Gerstel Inc.) in combination with a CIS-4 PTV injector (Gerstel). Sample preparation was modified from Hoffmann and Heiden (2000) and Park and Drake (2016) to include GC sniffing. Prior to analysis, the stir bars and thermal desorption unit tubes were conditioned for $1 \mathrm{~h}$ at $300^{\circ} \mathrm{C}$. Ten milliliters of milk was placed in $10-\mathrm{mL}$ amber vials with steel screw tops containing silicone septa faced in Teflon (Microliter Analytical) along with a PDMS coated stir-bar $(10 \mathrm{~mm} \times 0.5 \mathrm{~mm}$ thickness, Gerstel) placed in the samples directly. The vials were stirred for $1 \mathrm{~h}$ at ambient temperature $\left(21^{\circ} \mathrm{C}\right)$. The stir 
bars were washed with HPLC water (Fisher Chemicals, Fair Lawn, NJ), dried, and placed into clean thermal desorption tubes (Gerstel). Volatile compounds from the stir bars were thermally desorbed at $280^{\circ} \mathrm{C}$ assisted by cryofocusing at $-100^{\circ} \mathrm{C}$ for $5 \mathrm{~min}$. The GC inlet was then gradually increased to $275^{\circ} \mathrm{C}$ at $12^{\circ} \mathrm{C} / \mathrm{s}$, and held for $50 \mathrm{~min}$. The $\mathrm{GC}$ oven was initially held at $35^{\circ} \mathrm{C}$ for $3 \mathrm{~min}$ with a rate of $10^{\circ} \mathrm{C} / \mathrm{min}$ to $150^{\circ} \mathrm{C}$, held for $1 \mathrm{~min}$, then raised at a rate of $20^{\circ} \mathrm{C} / \mathrm{min}$ to $250^{\circ} \mathrm{C}$ and maintained for $5 \mathrm{~min}$. All analyses were performed at a constant flow rate of $1 \mathrm{~mL} / \mathrm{min}$ with helium and the effluent from the capillary column was split 1:1 between the MS and the ODP-3. The ODP-3 exit was maintained at $250^{\circ} \mathrm{C}$ and humidified with air at $30 \mathrm{~mL} /$ min. Scanning parameters were set from 30 to $350 \mathrm{~m} / \mathrm{z}$. The MS transfer line was maintained at $280^{\circ} \mathrm{C}$ with the quad at $150^{\circ} \mathrm{C}$ and source at $230^{\circ} \mathrm{C}$. Each sample was evaluated by at least 2 highly experienced sniffers (each with $>50 \mathrm{~h}$ previous experience with GC-O) who recorded aroma character, perceived intensity, and retention time.

\section{Compound Identification and Quantification}

Aroma active compounds recovered from milks were identified by aroma properties, the National Institute of Standards and Technology (NIST, 2014) mass spectral database, authentic standards injection, and retention indices calculation (Vandendool and Kratz, 1963) using an alkane series (Sigma-Aldrich) under identical GC-O/ MS conditions. Twenty-nine compounds, 7 of which were sulfur compounds, were selected for quantification based on aroma intensity and character, and previous literature (Colahan-Sederstrom and Peterson, 2005; Vazquez-Landaverde et al., 2006). Quantification of selected compounds were made on an Agilent 7890B GC applied to an Agilent 7000C triple quad MS (MS/MS) and sulfur selective FPD (Agilent Technologies Inc.) equipped with a ZB- $5 \mathrm{~ms}$ ( $30 \mathrm{~m}$ length $\times 0.25 \mathrm{~mm}$ i.d. $\times$ $0.25 \mu \mathrm{m}$ film thickness; Phenomenex) column. Sample introduction was accomplished using a CTC Analytics CombiPal Autosampler (CTC Analytics). Vials were equilibrated for $25 \mathrm{~min}$ at $35^{\circ} \mathrm{C}$ with $4 \mathrm{~s}$ of pulsed 250 rpm agitation. A single 50/30 um DVB/CAR/PDMS (Supelco) 1-cm fiber was used for all analyses. The SPME fiber was exposed to the samples for $40 \mathrm{~min}$ at a depth of $31 \mathrm{~mm}$. The fiber was retracted and injected at $50 \mathrm{~mm}$ in the GC inlet for $5 \mathrm{~min}$. The GC oven was initially held at $35^{\circ} \mathrm{C}$ for 3 min with a gradual increase of $10^{\circ} \mathrm{C} / \mathrm{min}$ to $150^{\circ} \mathrm{C}$, held for $1 \mathrm{~min}$, then raised at a rate of $20^{\circ} \mathrm{C} / \mathrm{min}$ to $250^{\circ} \mathrm{C}$ and maintained for $5 \mathrm{~min}$. The MS transfer line was maintained at $250^{\circ} \mathrm{C}$ with the quad at $150^{\circ} \mathrm{C}$ and source at $250^{\circ} \mathrm{C}$. The flow rate of helium quench gas and nitrogen collision gas was 1.0 $\mathrm{mL} / \mathrm{min}$ and $2.5 \mathrm{~mL} / \mathrm{min}$, respectively. Effluent from the capillary column was split 1:1 between the MS and FPD. The FPD for sulfur compounds was set to $325^{\circ} \mathrm{C}$ for transfer line, air $100 \mathrm{~mL} / \mathrm{min}$, and hydrogen $60 \mathrm{~mL} /$ min.

The multiple reaction monitoring transitions and collision energies $(\mathbf{C E})$ were developed to identify the most intensive/unique ions to the analytes of interest (Langen et al., 2013; Hopfer et al., 2016). The precursor ions for each compound were selected based on their mass spectra obtained from the full-scan single MS of authentic standards. The product ion scanning was acquired by GC-MS/MS using product ion scan mode with different $\mathrm{CE}$ of $3,5,10,15,20,25$, or $30 \mathrm{~V}$ with nitrogen gas. To obtain optimal ion abundances, selected compounds were tested again with 1, 2, 3, 4, and $5 \mathrm{~V}$ of $\mathrm{CE}$ based on compound volatility and molecular weight. The most intense product ion was chosen for the quantifier, and the second or third most intense product ions were selected for qualitative ions. Final multiple reaction monitoring transition was optimized with chosen $\mathrm{CE}$ to have optimal ion abundances for quantification (Table 1). Dwell times were set to ensure 3 to 3.1 cycles over a peak. MassHunter Qualitative and Quantitative analysis software (Agilent Technologies Inc.) was used for data analysis.

External standard curves for 29 selected compounds were constructed using milk (skim HTST) as the matrix. Each standard stock solution was prepared, then diluted at either 1:2, 1:5, 1:10, 1:20, or 1:50 strength and the skim milk was then spiked with $20 \mu \mathrm{L}$ of each concentration level. In addition to the milk and standard, 2 internal standards $(20 \mu \mathrm{L}$ of ethyl methyl sulfide in ethyl ether at $1.65 \mathrm{mg} / \mathrm{kg}$ and $20 \mu \mathrm{L}$ of 2-methyl3-heptanone in ethyl ether at $81 \mathrm{mg} / \mathrm{kg}$ ) were also added to each 20-mL amber SPME vial. The response ratio of the quantifier ion to that of internal standard was calculated. All samples were injected using SPME fiber in triplicate at each concentration level, and linear regression plots were used to determine the calibration equations.

\section{Statistical Analyses}

The GLM procedure of SAS (version 9.4, SAS Institute Inc., Cary, NC) was used to determine the effect of fat level (0.2 and $2 \%$ fat milk), heat treatment (HTST, DSI-UP, and IND-UP), and time of storage $\left(3,7\right.$, and $14 \mathrm{~d}$ at $\left.4^{\circ} \mathrm{C}\right)$ on descriptive sensory analysis attribute scores. The time variable (continuous) was a mean-centered (Misawa et al., 2016) variable to avoid co-linearity effects on statistical analysis (Glantz and 
Slinker, 2001) and named as TimeT in models. Time was transformed by subtracting the mean time from each of the individual time and using these meancentered data in the statistical analysis to provide a better point of reference in parsing the relative strength of main effects and interaction effects of factors in the model. If the $F$-value for the full model was significant $(P<0.05)$, then significance $(P<0.05)$ of each factor and their interactions was determined. The category effects of fat level, heat, replicate, and panelist and their interactions were tested for significance using the interaction term of fat $\times$ heat $\times$ replicate $\times$ panelist, whereas the linear effects of the continuous variable of time and interactions of the categorical variables were tested for significance using the full model error. The analysis for all factors and their interactions was done first, if the $F$-value for the full model was $<0.05$, then a stepwise process was done to remove all nonsignificant terms from the model to produce a final reduced model and a type III sum of squares table was produced and the $\mathrm{R}^{2}$ for the reduced model was reported.

Concentrations of selected compounds were analyzed by ANOVA (fat content $\times$ storage time $\mathrm{x}$ heat treatment) with means separation using Fisher's least significant difference test. Principal component analysis was applied to visualize and differentiate aroma active compounds between milk treatments. All statistical analyses were performed using XLSTAT (version 2017, Addinsoft, New York, NY) at a significance of $P<$ 0.05 .

\section{RESULTS AND DISCUSSION}

\section{Proximate Analysis}

Skim milk composition was $0.068 \% \pm 0.004$ fat, $4.72 \% \pm 0.02$ lactose, $3.12 \% \pm 0.01$ protein, and $8.95 \%$ $\pm 0.03 \mathrm{TS}$. The $2 \%$ fat milks averaged $1.96 \% \pm 0.004$ fat, $4.63 \% \pm 0.02$ lactose, $3.06 \% \pm 0.01$ protein, and $10.7 \% \pm 0.03$ TS. Milk composition was not different between treatments at each fat level $(P>0.05)$. The particle size distribution $\mathrm{d}(0.9)[90 \%$ of the total fat globule volume in the sample comes from particles with diameter that lies below the $\mathrm{d}(0.9)]$ was $<1.5 \mu \mathrm{m}$ for all milks, indicating appropriate homogenization. No differences $(P>0.05)$ were observed in milk fat particle size among the $2 \%$ milk treatments [mean d(0.9) for $2 \%$ milk; HTST $=1.26$, DSI-UP $=1.18$, and IND-UP $=1.37 \mu \mathrm{m}]$, which were in the range of particle size distribution [range of d(0.9) from 1.19 to $1.81 \mu \mathrm{m}$ ] reported by Caplan and Barbano (2013). All milks were negative for alkaline phosphatase, indicating complete pasteurization.

\section{Descriptive Sensory Analysis}

Trained panel profiling of milks demonstrated that the milks were differentiated by overall aroma intensity, sweet aromatic, cooked, and sulfur/eggy flavors among heat treatments and across time (Tables 2 and 3 and Figure 1). Fat level (skim vs. $2 \%$ fat) had only a minor direct influence on most trained panel perception of flavor, except for milk fat flavor (Table 2), as would be expected. Where fat did have an effect, it was manifested as an interaction effect in combination with heat treatment (Table 2) for overall aroma intensity and sweet aromatic, sulfur, and astringent flavors.

Fat level did not affect overall aroma intensity $(P>$ $0.05)$, but did affect $(P<0.05)$ all other sensory attributes (Tables 2 and 3), but the magnitude of the effect of fat was very small compared with heat treatment as seen from the very small proportion of the total type III sum of square explained by fat terms in the ANOVA model. The HTST milks had lower $(P<0.05)$ scores for all sensory attributes except sweet taste (Table 3 ). The UP milks treated by DSI or IND were distinguished by higher $(P<0.05)$ aroma intensity, cooked and sulfur/ eggy flavors, and astringency compared with HTST milk (Table 3). The 2 UP treatments also were distinct in sensory profile. Milk processed by DSI-UP had higher overall aroma intensity and sulfur/eggy flavor (Table $3)$, whereas IND-UP milks had a higher $(P<0.05)$ intensity of sweet aromatic flavors. Time of storage had the largest effect $(P<0.05)$ on overall aroma intensity and sulfur flavor score with these scores decreasing with time of storage (Figure 1). There was an interaction $(P<0.05)$ of time of storage and heat treatment (Table 2) with overall aroma intensity decreasing more with time for UP milks than HTST milk and IND-UP milk decreasing in sulfur intensity more with time than DSI-UP milk (Figure 1).

Distinct cooked and sulfur/eggy flavors in milk have been reported as characteristic of UP/UHT milk due to the excessive heat applied compared with HTST (Liem et al., 2016; Lee et al., 2017). Sulfur-containing compounds contributing to the cooked and sulfur flavors are attributed to denaturation of serum protein, mainly $\beta-\mathrm{LG}$ and sulfur-containing AA in the serum protein fraction (Hutton and Patton, 1952; Mehta, 1980; AlAttabi et al., 2009). Cystine, present at high amounts in serum protein, is known as a key precursor of hydrogen sulfide and carbon disulfide under severe heat treatment (Al-Attabi et al., 2009). These compounds are known as major sulfur compounds responsible for cooked and sulfur flavors (Vazquez-Landaverde et al., 2005, 2006). The difference in the intensity of sulfur/ eggy flavor between DSI-UP and IND-UP could be at- 
Table 2. Analysis of variance type III sum of squares for descriptive sensory profiles of HTST and ultra-pasteurized skim and $2 \%$ fat milks at d 3,7 , and 14 postprocessing at $4^{\circ} \mathrm{C}$

\begin{tabular}{|c|c|c|c|c|c|c|c|}
\hline \multirow[b]{2}{*}{ Factor $^{1}$} & \multicolumn{7}{|c|}{ Sensory attribute } \\
\hline & $\begin{array}{l}\text { Overall } \\
\text { aroma }\end{array}$ & $\begin{array}{l}\text { Sweet } \\
\text { aromatic }\end{array}$ & Cooked & $\begin{array}{l}\text { Sulfur } \\
\text { /eggy }\end{array}$ & Milkfat & $\begin{array}{l}\text { Sweet } \\
\text { taste }\end{array}$ & Astringent \\
\hline Fat & 0.00 & $1.55^{*}$ & $1.47^{*}$ & $0.21 *$ & 952.05* & $0.15^{*}$ & $6.07^{*}$ \\
\hline Heat & $311.47^{*}$ & $73.56^{*}$ & $152.91^{*}$ & $327.21^{*}$ & 0.02 & $6.12 *$ & $112.17^{*}$ \\
\hline Replicate & 0.02 & 0.21 & 0.20 & $0.37^{*}$ & $0.07^{*}$ & 0.02 & 0.10 \\
\hline Panelist & 0.09 & 0.42 & $0.48^{*}$ & 0.42 & 0.03 & 0.15 & 0.12 \\
\hline Heat $\times$ replicate & NS & NS & NS & NS & NS & NS & $0.77^{*}$ \\
\hline Fat $\times$ heat $\times$ replicate $\times$ panelist & 5.73 & 3.72 & 4.15 & 3.67 & 0.85 & 2.57 & 4.41 \\
\hline TimeT & $67.13^{*}$ & $13.48^{*}$ & $5.45^{*}$ & $62.63^{*}$ & NS & NS & 0.02 \\
\hline TimeT $\times$ fat & NS & $0.71^{*}$ & $0.35 *$ & $0.50^{*}$ & NS & NS & $0.76^{*}$ \\
\hline TimeT $\times$ heat & $11.18^{*}$ & $1.60^{*}$ & NS & $31.32 *$ & NS & NS & $0.70^{*}$ \\
\hline TimeT $\times$ replicate & NS & NS & NS & $0.26^{*}$ & NS & NS & NS \\
\hline $\mathrm{R}^{2}$ & 0.912 & 0.806 & 0.877 & 0.944 & 0.994 & 0.400 & 0.836 \\
\hline
\end{tabular}

${ }^{1}$ Heat had 3 levels (DSI-UP $=$ ultra-pasteurization by direct steam injection; IND-UP = ultra-pasteurization by indirect heating); fat had 3 levels skim $=$ milk with $0.2 \%$ fat and $2 \%=$ milk with $2 \%$ fat; replicate had 3 levels, replicate 1,2 , and 3 ; TimeT is the mean centered time with 3 levels, 3,7 , and $14 \mathrm{~d}$.

${ }^{2} \mathrm{NS}=$ model term not significant $(P>0.05)$.

$* P<0.05$.

tributed to interactions between flavor compounds and serum protein. Denatured unfolded protein contains hydrophobic pockets, which result in hydrophobic interactions and binding with flavor compounds (Reineccius, 2006). Although IND-UP had higher serum protein denaturation than DSI-UP (Lee et al., 2017), the less intense sulfur flavor by IND-UP would be expected due to the extent of flavor binding in relation to the degree of protein denaturation.

Higher sweet aromatic flavor in IND-UP milk (Table 3) may be related to the effect of the timetemperature profile of DSI-UP, IND-UP, and HTST (Lee et al., 2017). Lee et al. (2017) documented that IND-UP generated a higher total heat exposure of the milk than DSI-UP, which was evaluated by furosine content. The higher furosine content of IND-UP suggests greater Maillard reactions and lactose degradation, which may contribute to sweet aromatic flavors. Potent sweet aromatic volatile compounds include maltol, 2-acetyl-1-pyrroline, furaneol, and sotolon in heated milk (Scanlan et al., 1968; Calvo and Hoz, 1992; Colahan-Sederstrom and Peterson, 2005). Decreases in aroma and flavor intensity of milks during storage was observed, consistent with previous studies (Chapman et al., 2001; Lee et al., 2017). However, UP milks remained distinct from HTST milks. Dissipated aroma and flavor during milk storage in our study (Figure 1) could be associated with diffusion of highly volatile compounds or oxidation of sulfur compounds or lipids (Al-Attabi et al., 2009).

Table 3. Least squares means for descriptive sensory profiles of skim and $2 \%$ fat milks with different thermal treatments (HTST and ultrapasteurized milks) stored at $\mathrm{d} 3,7$, and 14 postprocessing at $4^{\circ} \mathrm{C}$

\begin{tabular}{|c|c|c|c|c|c|c|c|c|}
\hline Factor & Treatment $^{1}$ & \multicolumn{7}{|c|}{ Sensory attribute ${ }^{2}$} \\
\hline Fat & $2 \%$ & $2.3^{\mathrm{a}}$ & $1.7^{\mathrm{a}}$ & $3.8^{\mathrm{a}}$ & $0.70^{\mathrm{b}}$ & 2.2 & $2.1^{\mathrm{b}}$ & $2.0^{\mathrm{b}}$ \\
\hline \multirow[t]{2}{*}{ Heat } & HTST & $1.5^{\mathrm{c}}$ & $1.6^{\mathrm{b}}$ & $3.1^{\mathrm{c}}$ & $0.0^{3}$ & $1.1^{\mathrm{a}}$ & $2.2^{\mathrm{a}}$ & $1.5^{\mathrm{b}}$ \\
\hline & DSI-UP & $2.9^{\mathrm{a}}$ & $1.3^{\mathrm{c}}$ & $4.2^{\mathrm{a}}$ & $1.55^{\mathrm{a}}$ & $1.1^{\mathrm{a}}$ & $2.0^{\mathrm{b}}$ & $2.4^{\mathrm{a}}$ \\
\hline
\end{tabular}

\footnotetext{
${ }^{a-c}$ Least squares means within a column are different within fat level and heat treatment if they do not share a common superscript $(P<0.05)$. ${ }^{1}$ DSI-UP $=$ ultra-pasteurization by direct steam injection; IND-UP $=$ ultra-pasteurization by indirect heating; skim $=$ milk with $0.2 \%$ fat; and $2 \%=$ milk with $2 \%$ fat.

${ }^{2}$ Attribute intensities were scored on a 0 - to 15-point universal intensity scale (Meilgaard et al., 2007). Fluid milk flavors fall between 0 and 4 on this scale (Croissant et al., 2007; Drake et al., 2007; McCarthy et al., 2017).

${ }^{3} 0.0=$ not detected.
} 


\section{Volatile Compound Analysis}

Fifty-five and 45 aroma active compounds were detected in milks by SPME-GC-O and SBSE-GC-O, respectively. As expected, some highly volatile compounds (e.g., sulfur-containing compounds) were detected by SPME-GC-O and not by SBSE-GC-O (Table 4). In contrast, some higher molecular weight aroma active compounds (e.g., acids and lactones) identified by SBSE-GC-O were either tentatively identified or not detected by SPME-GC-O. Generally, SPME collects volatile compounds from headspace with a bias toward more highly volatile compounds (Drake et al., 2010; Smith et al., 2016). Headspace compounds play a major role in aroma perception, but may not represent comprehensive aroma profiles (Hoffmann and Heiden, 2000). On the other hand, SBSE was more effective to profile volatiles with heavy molecular weight or semivolatile compounds of milk, especially when applied with the multidimensional techniques of olfactometry and MS. The combination of the 2 extraction methods provided an effective platform to evaluate aroma active volatile and semi-volatile compounds and define/screen key flavor compounds, which span a wide range in milk. The majority of the aroma active compounds characterized in this study were previously identified in UP or UHT milk, but 17 compounds were newly detected in this study (Table 4). Among those 17 compounds, 12 compounds were positively identified and remaining 5 compounds were tentatively identified by either SPME or SBSE. Based on the frequency of detection among the 6 milks, odor characteristics, and literature (ColahanSederstrom and Peterson, 2005; Vazquez-Landaverde et al., 2006), 29 potent aroma active compounds were selected for quantification.

The combination of GC-MS followed by GC-MS/MS techniques used in this study extended the number of chemical class in one analytical run, unlike applying solvent extraction methods to cover multi-classes or high molecular weight volatile compounds (ColahanSederstrom and Peterson, 2005; Potineni and Peterson, 2005; Czerny and Schieberle, 2007). Confirmation of
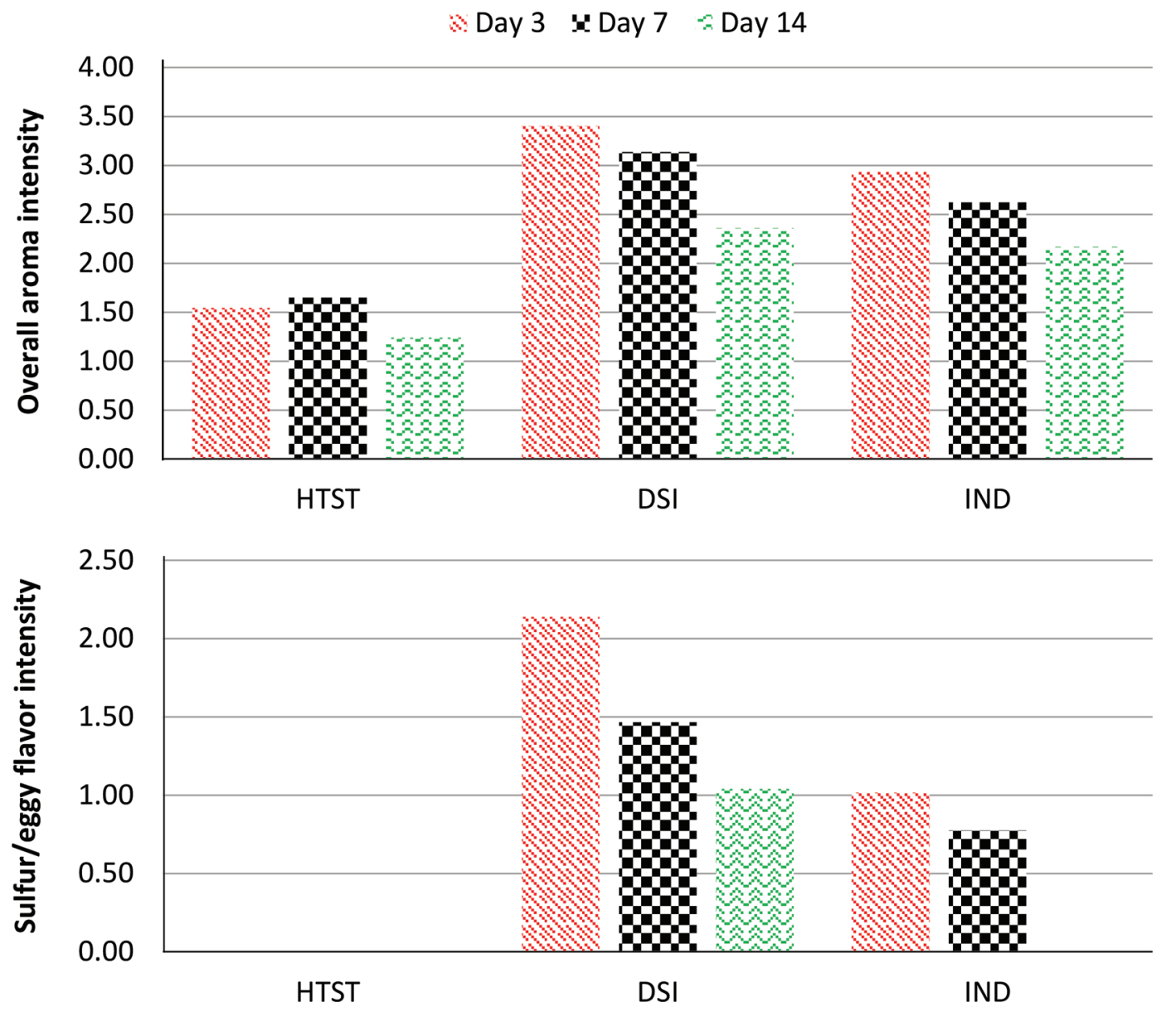

Figure 1. Trained panel intensities for overall aroma and sulfur/eggy flavor with different heat treatment and storage. DSI $=$ ultra-pasteurization by direct steam injection; IND = ultra-pasteurization by indirect heating. Color version available online. 
Table 4. Aroma active compounds of milk detected by gas chromatography-olfactometry (GC-O) using headspace solid-phase micro extraction (HS-SPME) and stir bar sorptive extraction (SBSE)

\begin{tabular}{|c|c|c|c|c|c|c|}
\hline \multicolumn{2}{|c|}{$\mathrm{RI}^{1}$} & \multirow[b]{2}{*}{ Compound } & \multirow{2}{*}{$\begin{array}{l}\text { Odor } \\
\text { description }\end{array}$} & \multicolumn{2}{|c|}{ Identification $^{3}$} & \multirow[b]{2}{*}{$\begin{array}{l}\text { Previously identified } \\
\text { in UP or UHT milk }\end{array}$} \\
\hline ZB-5 & Wax & & & SPME & SBSE & \\
\hline 544 & & Hydrogen sulfide & Sulfur/egg & $\mathrm{O}, \mathrm{RI}, \mathrm{MS}$ & $\mathrm{ND}^{6}$ & $1,16,17$ \\
\hline 564 & 789 & Dimethyl sulfide & Chemical/sulfur & $\mathrm{O}, \mathrm{RI}, \mathrm{MS}$ & ND & $1,3,4,13,16,17$ \\
\hline 568 & 770 & Carbon disulfide & Cooked & $\mathrm{O}, \mathrm{RI}, \mathrm{MS}$ & ND & $1,16,17$ \\
\hline 596 & 941 & 2-Butanone & Plastic & $\mathrm{O}, \mathrm{RI}, \mathrm{MS}$ & ND & 3 \\
\hline 607 & 988 & Diacetyl & Diacetyl & $\mathrm{O}, \mathrm{RI}, \mathrm{MS}$ & ND & $4,6,7,15$ \\
\hline 645 & 903 & 2-Methylbutanal & Cooked/malty & $\mathrm{O}, \mathrm{RI}, \mathrm{MS}$ & $\mathrm{ND}$ & $1,3,4,13$ \\
\hline 665 & 920 & 3-Methylbutanal & Cooked/malty & $\mathrm{O}, \mathrm{RI}, \mathrm{MS}$ & $\mathrm{O}, \mathrm{RI}, \mathrm{MS}$ & $1,3,4,13$ \\
\hline 701 & & Acetoin & Sweet/milky & $\mathrm{O}, \mathrm{RI}, \mathrm{MS}$ & ND & \\
\hline 752 & 1,063 & Dimethyl disulfide & Earthy/sulfur & $\mathrm{O}, \mathrm{RI}, \mathrm{MS}$ & ND & $1,3,14,16,17$ \\
\hline 767 & 1,602 & Dimethyl sulfoxide & Sulfur/garlic & $\mathrm{O}, \mathrm{RI}, \mathrm{MS}$ & ND & 1,16 \\
\hline 785 & 1,109 & 2-Hexanone & Metallic/burnt & $\mathrm{O}, \mathrm{RI}$ & $\mathrm{ND}$ & 4 \\
\hline 808 & 1,094 & Hexanal & Grass & $\mathrm{O}, \mathrm{RI}, \mathrm{MS}$ & $\mathrm{O}, \mathrm{RI}, \mathrm{MS}$ & $3,4,6,8,14$ \\
\hline 823 & & Butanoic acid & Acidic/cheesy & $\mathrm{O}, \mathrm{RI}$ & $\mathrm{O}, \mathrm{RI}, \mathrm{MS}$ & $2,7,11$ \\
\hline 831 & 1,247 & Methyl pyrazine & Potato/earthy & $\mathrm{O}, \mathrm{RI}$ & ND & \\
\hline 857 & 1,465 & Furfural & Barny/brothy & $\mathrm{O}, \mathrm{RI}, \mathrm{MS}$ & $\mathrm{O}, \mathrm{RI}, \mathrm{MS}$ & $3,4,10,11$ \\
\hline 858 & 1,054 & Ethyl 2-methylbutanoate & Fruity & $\mathrm{O}, \mathrm{RI}$ & ND & 7 \\
\hline 861 & 1,668 & Furfuryl alcohol & Burnt/woody & $\mathrm{O}, \mathrm{RI}$ & $\mathrm{O}, \mathrm{RI}, \mathrm{MS}$ & 8 \\
\hline 867 & 1,714 & Isovaleric acid & Sweaty/sour & $\mathrm{O}, \mathrm{RI}$ & ND & 11 \\
\hline 877 & 1,330 & 2-Methyl-3-furanthiol & Sulfur/nutty/meaty & $\mathrm{O}, \mathrm{RI}$ & $\mathrm{ND}$ & \\
\hline 897 & 1,155 & 2-Heptanone & Cooked & $\mathrm{O}, \mathrm{RI}, \mathrm{MS}$ & $\mathrm{O}, \mathrm{RI}, \mathrm{MS}$ & $4,6,13$ \\
\hline 898 & 1,183 & Heptanal & Earthy/fatty & $\mathrm{O}, \mathrm{RI}, \mathrm{MS}$ & $\mathrm{O}, \mathrm{RI}, \mathrm{MS}$ & $3,4,8,14$ \\
\hline 911 & 1,127 & Ethyl valerate & Fruity & $\mathrm{O}, \mathrm{RI}, \mathrm{MS}$ & ND & \\
\hline 920 & 1,481 & Methional & Potato/earthy & $\mathrm{O}, \mathrm{RI}, \mathrm{MS}$ & $\mathrm{O}, \mathrm{RI}$ & $1,2,7,9,11,12$ \\
\hline 930 & 1,341 & 2-Acetyl-1-pyrroline & Popcorn/cereal & $\mathrm{O}, \mathrm{RI}$ & $\mathrm{ND}$ & $2,9,11$ \\
\hline 944 & 1,502 & Benzaldehyde & Cooked/nutty & $\mathrm{O}, \mathrm{RI}, \mathrm{MS}$ & $\mathrm{O}, \mathrm{RI}, \mathrm{MS}$ & 3,5 \\
\hline 949 & 1,014 & $\alpha$-Pinene & Feed & $\mathrm{O}, \mathrm{RI}, \mathrm{MS}$ & $\mathrm{O}, \mathrm{RI}, \mathrm{MS}$ & \\
\hline 961 & 1,151 & Isobutyl butanoate & Sweet/fruity & $\mathrm{O}, \mathrm{RI}, \mathrm{MS}$ & $\mathrm{O}, \mathrm{RI}, \mathrm{MS}$ & \\
\hline 984 & 1,369 & Dimethyl trisulfide & Garlic/cabbage & $\mathrm{O}, \mathrm{RI}, \mathrm{MS}$ & $\mathrm{O}, \mathrm{RI}, \mathrm{MS}$ & $1,16,17$ \\
\hline 990 & 1,314 & 1-Octen-3-one & Mushroom & $\mathrm{O}, \mathrm{RI}, \mathrm{MS}$ & $\mathrm{ND}$ & 11 \\
\hline 995 & 1,288 & Octanal & Grass & $\mathrm{O}, \mathrm{RI}, \mathrm{MS}$ & $\mathrm{O}, \mathrm{RI}, \mathrm{MS}$ & $3,4,8,14$ \\
\hline 1,003 & 1,433 & 1-Octen-3-ol & Mushroom & $\mathrm{O}, \mathrm{RI}, \mathrm{MS}$ & ND & \\
\hline 1,020 & & Limonene & Lemon/fruity & $\mathrm{O}, \mathrm{RI}, \mathrm{MS}$ & $\mathrm{O}, \mathrm{RI}, \mathrm{MS}$ & 8 \\
\hline 1,052 & & 2-Acetylthiazole & Earthy & $\mathrm{O}, \mathrm{RI}$ & $\mathrm{O}, \mathrm{RI}$ & \\
\hline 1,061 & & Furaneol & Sweet & $\mathrm{O}, \mathrm{RI}$ & $\mathrm{O}, \mathrm{RI}$ & 11 \\
\hline 1,071 & 2,120 & p-Cresol & Earthy/barny & $\mathrm{O}, \mathrm{RI}$ & $\mathrm{O}, \mathrm{RI}, \mathrm{MS}$ & \\
\hline 1,081 & 1,382 & 2-Nonanone & Sweet/flowery & $\mathrm{O}, \mathrm{RI}, \mathrm{MS}$ & $\mathrm{O}, \mathrm{RI}, \mathrm{MS}$ & 4,6 \\
\hline 1,091 & 1,808 & Guaiacol & Earthy & $\mathrm{O}, \mathrm{RI}$ & $\mathrm{O}, \mathrm{RI}, \mathrm{MS}$ & \\
\hline 1,110 & 2,043 & Maltol & Sweet & $\mathrm{O}, \mathrm{RI}, \mathrm{MS}$ & $\mathrm{O}, \mathrm{RI}, \mathrm{MS}$ & 15 \\
\hline 1,111 & 1,796 & 2-Acetyl-2-thiazoline & Nutty & $\mathrm{O}, \mathrm{RI}$ & ND & $2,7,9,11,12$ \\
\hline 1,120 & 2,193 & Sotolon & Cooked/spicy & $\mathrm{O}, \mathrm{RI}$ & ND & 11 \\
\hline 1,129 & 1,927 & Phenyl ethanol & Flowery & $\mathrm{O}, \mathrm{RI}$ & ND & \\
\hline 1,147 & 1,537 & (E)-2-nonenal & Oily & $\mathrm{O}, \mathrm{RI}$ & $\mathrm{O}, \mathrm{RI}, \mathrm{MS}$ & 11 \\
\hline 1,155 & 1,582 & (E,Z)-2,6-nonadienal & Herb/nutty & $\mathrm{O}, \mathrm{RI}$ & $\mathrm{O}, \mathrm{RI}, \mathrm{MS}$ & 7,11 \\
\hline 1,180 & & Octanoic acid & Acidic/waxy & ND & $\mathrm{O}, \mathrm{RI}, \mathrm{MS}$ & $2,7,11,15$ \\
\hline 1,183 & 1,426 & Ethyl octanoate & Mellow sweet & $\mathrm{O}, \mathrm{RI}$ & $\mathrm{O}, \mathrm{RI}$ & \\
\hline 1,200 & & Decanal & Soapy & ND & $\mathrm{O}, \mathrm{RI}, \mathrm{MS}$ & 4 \\
\hline 1,225 & 2,592 & Phenylacetic acid & Floral & $\mathrm{O}, \mathrm{RI}$ & $\mathrm{O}, \mathrm{RI}$ & 11 \\
\hline 1,271 & 1,988 & $\delta$-Octalactone & Bread/sweet & $\mathrm{O}, \mathrm{RI}$ & $\mathrm{O}, \mathrm{RI}, \mathrm{MS}$ & 2,11 \\
\hline 1,280 & & Nonanoic acid & Acidic/sweaty & ND & $\mathrm{O}, \mathrm{RI}, \mathrm{MS}$ & 11 \\
\hline 1,347 & & $(\mathrm{E}, \mathrm{E})-2,4$-decadienal & Fatty & ND & $\mathrm{O}, \mathrm{RI}, \mathrm{MS}$ & \\
\hline 1,354 & 2,227 & 2-Aminoacetophenone & Tortilla/grain & $\mathrm{O}, \mathrm{RI}$ & $\mathrm{O}, \mathrm{RI}$ & 15 \\
\hline 1,367 & & Decanoic acid & Cosmetic/soapy & ND & $\mathrm{O}, \mathrm{RI}, \mathrm{MS}$ & $7,11,15$ \\
\hline 1,409 & 2,473 & Skatole & Fecal/foul & $\mathrm{O}, \mathrm{RI}$ & $\mathrm{O}, \mathrm{RI}$ & 11 \\
\hline 1,420 & & Vanillin & Vanilla & ND & $\mathrm{O}, \mathrm{RI}, \mathrm{MS}$ & 2,7 \\
\hline 1,486 & & $\gamma$-Decalactone & Sweet/caramel & ND & $\mathrm{O}, \mathrm{RI}, \mathrm{MS}$ & 11 \\
\hline 1,494 & & $\delta$-Decalactone & Fruity & ND & O, RI, MS & $2,6,7,11$ \\
\hline 1,553 & 2,300 & $\delta$-Undecalactone & Butter sweet & $\mathrm{O}, \mathrm{RI}$ & $\mathrm{O}, \mathrm{RI}, \mathrm{MS}$ & \\
\hline 1,593 & 2,493 & Dodecanoic acid & Soapy & $\mathrm{O}, \mathrm{RI}$ & $\mathrm{O}, \mathrm{RI}, \mathrm{MS}$ & \\
\hline 1,649 & & $\gamma$-Dodecalactone & Sweet/grain & $\mathrm{O}, \mathrm{RI}$ & $\mathrm{O}, \mathrm{RI}, \mathrm{MS}$ & 2 \\
\hline 1,693 & & 2-Pentadecanone & Sweet/sugar & ND & $\mathrm{O}, \mathrm{RI}, \mathrm{MS}$ & \\
\hline 1,753 & & Tetradecanoic acid & Baby powder & ND & $\mathrm{O}, \mathrm{RI}, \mathrm{MS}$ & \\
\hline 1,779 & 2,425 & $\delta$-Dodecalactone & Sweet/grain & $\mathrm{O}, \mathrm{RI}$ & $\mathrm{O}, \mathrm{RI}, \mathrm{MS}$ & 7,15 \\
\hline
\end{tabular}

${ }^{1}$ Retention indices (RI) calculated from GC-O on the ZB-5 (Phenomenex, Torrance, CA) and wax columns with SPME, and ZB-5 column with SBSE.

${ }^{2}$ Odor description at the GC sniffing port by SPME and SBSE.

${ }^{3}$ Aroma active compounds identification from SPME and SBSE by O = comparison of the odor description at the sniffing port to the reference; MS = mass spectrum obtained by GC-MS

${ }^{4}$ The compounds were previously identified in milk treated with ultrapasteurized (UP) or UHT by the authors given in parentheses; 1 (Vazquez-Landaverde et al., 2006); 2 (Belitz et al., 2009); 3 (Valero et al., 2001); 4 (Vazquez-Landaverde et al., 2005); 5 (Potineni and Peterson, 2005); 6 (Moid et al., 1994); 7 (Czerny and Schieberle, 2007); 8 (Marsili, 1999); 9 (Kokkinidou and Peterson, 2014); 10 (Jeon et al., 1978); 11 (Colahan-Sederstrom and Peterson, 2005); 12 (Troise et al.., 2014);13 (Contarini et al., 1997); 14 (Mestdagh et al., 2005); 15 (Scanlan et al., 1968); 16 (Al-Attabi et al., 2014); 17 (Simon et al., 2001).

${ }^{5}$ Literature numbers $1-8=$ UHT milk purchased from retail (heating type not addressed); $9-12=$ UHT milk processed in laboratory or pilot scale (heating type not addressed); $13=$ UHT milk processed by direct steam injection; $14-16=$ UHT milk processed by indirect heating; $17=$ UP milk processed by indirect heating. ${ }^{6} \mathrm{ND}=$ not detected. 
compounds was obtained by the ratio of 2 selected ions, one for quantification and one for qualification, which provided selective and sensitive response throughout MS/MS transition. In this study, optimization of MS/ MS was shown to be a key tool to integrate different classes of target compounds in milk including sulfur, ketones, aldehydes, free fatty acid, lactones, and furanones. This wide range of analyzable compounds has not been previously reported using the GC MS/MS technique in the field of dairy flavors.

Concentrations of selected aroma active compounds were distinct between UP and HTST milks across the storage days evaluated (Table 5). Regression coefficients for all calibration curves were $>0.95$. Consistent with sensory profile, skim and $2 \%$ milks mainly differed by volatile compounds derived from lipids, such as hexanal, diacetyl, 2-heptanone, and lactones. The HTST milk had lower concentrations of sulfur compounds, ketones, and Strecker aldehydes compared with UP milks. This result would explain the lower intensity of overall aroma and lack of characteristic cooked and sulfur flavors in HTST milk. The UP milks contained higher concentrations of Maillard reaction compounds (2 and 3-methylbutanal, furfural, 2-acetyl-1-pyrroline, benzaldehyde), methyl ketones (2-butanone, 2-heptanone), and sulfur-containing compounds (hydrogen sulfide, carbon disulfide, dimethyl sulfide, and so on) compared with HTST, which contribute to the higher intensity of cooked and sulfur/eggy flavors of UP milk. Within UP treatments, hydrogen sulfide, dimethyl trisulfide, and methional were predominant in DSI-UP and 2 and 3-methylbutanal, diacetyl, furfural, 2-heptanone, 2-acetyl-1-pyrroline, 2-aminoacetophenone, benzaldehyde, and dimethyl sulfide were potent compounds in IND-UP.

The fat content of the milk affected the concentration of sulfur and various compounds related to Maillard reactions. Higher concentrations of furfural, 2-acetyl1-pyrroline, 2-aminoacetophenone, and benzaldehyde were present in $2 \%$ milks compared with skim, whereas higher concentrations of hydrogen sulfide and dimethyl sulfide were detected in skim milk $(P<0.05)$. This could be related to fat-flavor compound interactions (Reineccius, 2006). Some of these compounds, such as furfural, 2-acetyl-1-pyrroline, and 2-aminoacetophenone, have relatively low partition coefficients, making the compounds more soluble in water. As such, fat content may decrease retention in the matrix and cause release of more of these compounds into the headspace of $2 \%$ milks. On the other hand, hydrogen sulfide and dimethyl sulfide were more readily detected in skim milks compared with $2 \%$ milks possibly due to fat interference. Christensen and Reineccius (1992) demonstrated that milk with higher fat content had a lower sensitivity to sulfur compounds by headspace analysis. Fat content can affect migration of some volatile compounds to the headspace (Belitz et al., 2009), and the concentration of flavor compounds and their perception (Drake et al., 2010; Yeh et al., 2017).

The fat level of milk also had an influence on the concentration of compounds derived from lipid regardless of the type of heat treatment, consistent with previous studies (Vazquez-Landaverde et al., 2005). Hexanal is derived from autoxidation of UFA in milk and can be promoted via decomposition of hydroperoxides by heat (Grosch, 1982). Diacetyl is known as an important contributor to the buttery note in heated milk (Scanlan et al., 1968). Methyl ketones are naturally present in milk but their formation can be enhanced by milk fat degradation during heat treatment (Cadwallader and Singh, 2009), $\beta$-oxidation of saturated fatty acids followed by decarboxylation of $\beta$-ketoacids (Grosch, 1982). Higher concentration of 2-heptanone would be expected in $2 \%$ milk, because milk fat contains $10 \%$ of the fatty acids $\mathrm{C} 6,8,10$, and 12 , which are precursors of odd-numbered carbon methyl ketones (C5, C7, C9, and C11; Vazquez-Landaverde et al., 2005). In addition, accelerated degradation of milk fat and hydroperoxides during thermal treatment can result in the formation of methyl ketones (Cadwallader and Singh, 2009). Also, milk contains $1 \%$ lipids as oxo fatty acids, which can be liberated as $\beta$-ketoacids and decarboxylated to methyl ketones of $\mathrm{C} 6-\mathrm{C} 16$ when the milk fat is heated in the presence of water (Grosch, 1982). Lactones are formed by hydrolysis of hydroxyl acids from triglycerides (Reineccius, 2006). Hydroxy acids have no flavor as long as they are bound to triglycerides; the formation of lactones and flavor from fat are increased with heat treatment of milk (Reineccius, 2006; Drake et al., 2010). These compounds are known as thermal lipid degradation products in UP milk (Colahan-Sederstrom and Peterson, 2005), contributing milkfat and sweet coconut-like flavors to milk and dairy products (Drake et al., 2001).

Increases in compounds associated with Maillard reactions, including 2 and 3 methylbutanal, furfural, 2-acetyl-1-pyrroline, 2-aminoacetophenone, and benzaldehyde were higher in 2\% UP milks than in HTST and skim milk, respectively. The concentration of these compounds was also higher in IND-UP compared with DSI-UP. Maillard reactions are one of the major pathways to develop flavors in milk and vary depending on the time-temperature profile (Reineccius, 2006). Because higher heat treatment can stimulate more Maillard reaction intermediates (Reineccius, 2006), more or higher concentrations of Maillard reaction compounds would be expected from IND-UP. A recent study by Lee et al. (2017) demonstrated that IND-UP was linked to 


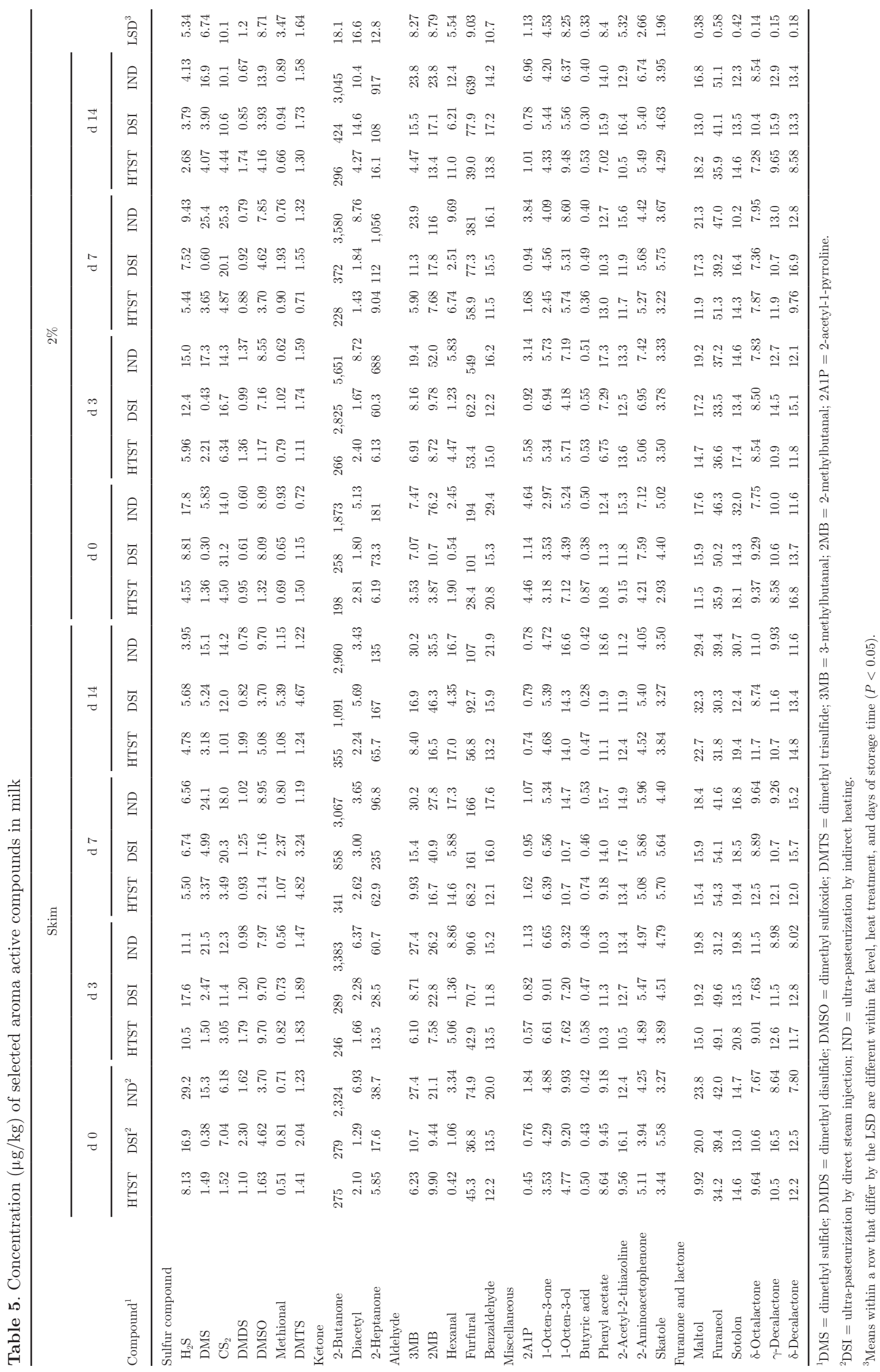


elevated Maillard reactions between lactose and lysine residues of milk because the total heat load of INDUP was higher compared with DSI-UP and HTST. In milk, Maillard reactions develop flavors associated with cooked and sweet aromatics, primarily under high heat ( $>140^{\circ} \mathrm{C}$; Belitz et al., 2009). Cooked flavor is affected by AA composition due to Maillard reactions being highly selective to the presence of specific AA to generate characteristic flavors. These AA include cysteine, lysine, methionine, leucine, isoleucine, valine, and tryptophan as flavor precursors (Reineccius, 2006; Belitz et al., 2009). Two- and 3-methylbutanal are Strecker degradation products of branched-chain AA, isoleucine and leucine, respectively (Belitz et al., 2009). Previous studies indicated increased or accumulation of 2- and 3-methylbutanal along with the heat severity (Contarini and Povolo, 2002; Vazquez-Landaverde et al., 2005; Belitz et al., 2009). 2-Aminoacetophenone was identified in milk protein powders as a characteristic tortilla/ corn flavor (Smith et al., 2016). Smith et al. (2016) suggested that degradation of tryptophan by heat and alkali conditions would be the primary source of 2-aminoacetophenone in milk proteins. Belitz et al. (2009) indicated that aminoacetophenone can be formed from oxidation of skatole, which is derived from tryptophan. Because tryptophan content is higher in the serum protein fraction than casein (Belitz et al., 2009), the formation of 2-aminoacetophenone could be more related to serum denaturation and would be expected to be more prevalent in UP milks. Benzaldehyde is formed from phenylalanine (Belitz et al., 2009). Compounds derived from sugar degradation during Maillard reaction were predominant and are likely to increase sweet aromatic flavors in UP milks. Furfural is derived from sugars during heat processing, and it was previously reported as an indicator of heat treatment and a key compound of UP milk (Colahan-Sederstrom and Peterson, 2005; Vazquez-Landaverde et al., 2005). Furfural is known as the precursor of melanoidins in Maillard reactions in milk, which contribute to its darker color (BeMiller and Whistler, 1996). 2-Acetyl-1-pyrroline has a popcorn aroma, and was present at higher concentration in IND-UP, possibly imparting its higher sweet/cooked flavor. It is commonly found in many dairy products, such as milk proteins (Smith et al., 2016), dried milk powders (Karagul-Yuceer et al., 2001), and dried whey powders (Carunchia Whetstine et al., 2005), because 2-acetyl-1-pyrroline is formed in Strecker degradation of proline and readily formed even under mild heating (Reineccius, 2006; Belitz et al., 2009).

The effect of sulfur compounds on milk flavor was predominant in UP treatments. These compounds included hydrogen sulfide, carbon disulfide, dimethyl sulfide, dimethyl disulfide, dimethyl trisulfide, and methional, similar with previous studies (VazquezLandaverde et al., 2006; Al-Attabi et al., 2009). Sulfur compounds have been associated with undesirable offflavors, such as intense cooked and sulfur/eggy flavors in UP/UHT milk, especially with the IND method (Vazquez-Landaverde et al., 2006; Al-Attabi et al., 2009). However, to our knowledge, no studies have directly compared the sulfur compounds or flavor of UP milk between DSI and IND methods. Moreover, unlike previous studies which have demonstrated IND processing to develop higher cooked and sulfur flavors due to higher heat severity than DSI (Al-Attabi et al., 2009), we found distinct sulfur/eggy flavors and compounds in DSI-UP. This could be attributed to the differences of the heating methods and the time-temperature profiles between DSI and IND. In regard to distinct cooked and sulfur flavors between these 2 heating methods, it should be noted that DSI also may have more severe heat effect because of direct contact of steam and milk, which can maximize heat absorption. The IND-UP processing keeps the heating of the medium and milk separate, but overall showed a higher and longer total heat exposure. This fundamental difference could lead to a distinct profile of sulfur compounds between DSI and IND, shown by a significant increase of dimethyl sulfide in IND-UP, possibly due to further oxidation of other sulfur compounds. The IND-UP milk has a higher content of dissolved oxygen than DSI-UP milk, the latter process removes water, oxygen, and some highly volatile compounds in the vacuum chamber (Datta et al., 2002). In contrast, DSI-UP had higher dimethyl trisulfide than IND-UP, which might suggest a different degradation of methionine between these 2 heating methods possibly related to differences in oxygen level. Future studies should investigate the mechanisms of sulfur-containing AA between DSI-UP and IND-UP.

The primary source of sulfur compounds in milk can be generated by 2 reactions; Strecker degradation of sulfur AA (cysteine/cystine and methionine), and liberation of sulfur compounds by serum protein denaturation (Mehta, 2015). Although sulfur compounds are naturally present in raw milk (Al-Attabi et al., 2009), dimethyl sulfide, dimethyl disulfide, dimethyl trisulfide, and methional are formed from Maillard reactions of methionine, whereas hydrogen sulfide and carbon disulfide can be derived from cysteine (Al-Attabi et al., 2009). Strecker degradation of methionine forms methional, which is readily oxidized to dimethyl sulfide, and dimethyl disulfide (Al-Attabi et al., 2009; Belitz et al., 2009). Methional was reported as a major off-flavor marker of UHT milk (Colahan-Sederstrom and Peterson, 2005; Troise et al., 2014). Dimethyl trisulfide is subsequently generated via oxidation of dimethyl sulfide where dimethyl sulfoxide is formed as an intermediate 
compound (Al-Attabi et al., 2009). Dimethyl sulfoxide is formed as an intermediate compound from oxidation of dimethyl sulfide (Shibamoto and Mihara, 1980), but its contribution to milk flavor is not confirmed yet.

Formation of hydrogen sulfide has been suggested in various ways: thermal denaturation of $\beta-\mathrm{LG}$ and the sulfur-containing AA in serum proteins (Hutton and Patton, 1952), Strecker degradation of cysteine and methionine (Belitz et al., 2009), and thermal degradation of thiamine (Dwivedi and Arnold, 1973). Denaturation of individual serum proteins and degradation of sulfur AA in serum protein have been hypothesized as primary sources of hydrogen sulfide in milk because serum proteins are more sensitive to heat than casein (Mehta, 2015). More importantly, cystine and cysteine are rich in serum protein, specifically $\beta$-LG component of serum protein, which can be key precursors of hydrogen sulfide during severe thermal processing (Al-Attabi et al., 2009). In particular, the $\beta$-LG in serum protein contains 5 cysteine residues capable of forming disulfide bonds as further flavor development (Mehta, 2015). $\beta$-Lactoglobulin is also more heat labile than $\alpha$-LA and can be completely denatured by UP (Belitz et al., 2009). When $\beta$-LG is denatured, the sulfhydryl groups readily release hydrogen sulfide and subsequently form disulfide bonds or further reacts with other milk proteins (Mehta, 2015). Other possible sources of formation of hydrogen sulfide in UP milks can be Strecker degradation of cysteine with diketones or thermal degradation of thiamin via rearrangement of the thiazole group liberating hydrogen sulfide (Al-Attabi et al., 2009). Future studies should identify the major source and formation of sulfur compounds in UP milks.

Correlation analysis confirmed relationships between cooked and sulfur/eggy flavors and the sulfur compounds hydrogen sulfide and carbon disulfide. Hydrogen sulfide was correlated with sulfur/eggy flavor $\left(\mathrm{R}^{2}=\right.$ 0.66; $P<0.05)$ and carbon disulfide was correlated with cooked flavor $\left(\mathrm{R}^{2}=0.83 ; P<0.05\right)$, and sulfur/eggy flavor $\left(\mathrm{R}^{2}=0.58 ; P<0.05\right)$. The correlation coefficient of dimethyl sulfide, dimethyl disulfide, dimethyl sulfoxide, and dimethyl trisulfide for cooked and sulfur/eggy flavors were under 0.50. Previous research suggested that hydrogen sulfide and carbon disulfide have a linear relationship with either higher heat temperature or cooked/heated flavor of milk (Hutton and Patton, 1952; Christensen and Reineccius, 1992; Vazquez-Landaverde et al., 2006). Carbon disulfide has been an indicator of heat treatment (Vazquez-Landaverde et al., 2006) and is a breakdown product of other sulfur compounds (Urbach, 1993). The concentration of sulfhydryl groups decreases over time due to oxidation, whereas that of disulfide bonds increases (Al-Attabi et al., 2009). These reactions could explain the higher sensory intensity and concentration of sulfur compounds in freshly processed milks and further the change of sulfur flavor and sulfur compound profiles over storage.

\section{Relationship Between Volatile Compounds and Sensory Attributes}

Principal component analysis was applied to visualize changes in flavor compound concentrations of milk processed with different heat treatments (Figures 2 and $3)$. The results revealed that most aroma active compounds were associated with UP milks by either DSI or IND at both fat levels, which pinpoints the distinct flavor differences between HTST and UP milks, and the relative lack of flavor of HTST milk. Comparing UP treatments, IND was more related to compounds derived from sugar degradation and Maillard reactions such as furfural, 2-acetyl-1-pyrroline, and maltol, which explains the higher sweet aromatic flavor in IND-UP milk. The IND-UP milks were also associated with sulfur compounds including dimethyl sulfoxide and dimethyl sulfide, possibly contributors to sulfur/eggy and cooked flavors. However, DSI-UP was more strongly associated with sulfurous compounds such as hydrogen sulfide, dimethyl trisulfide, and methional, which likely affect sulfur and cooked flavors in DSI-UP. Differentiation of sulfur compounds between UP treatments suggests that different AA precursors may be involved in the different heating mechanisms between IND and DSI, leading to distinct breakdown products and the distinct sensory profiles. Increased dimethyl sulfide in IND-UP may indicate further oxidation of methionine/dimethyl disulfide due to longer heating and cooling times (Lee et al., 2017). Dimethyl trisulfide in DSI-UP suggests Strecker degradation of methionine to methional and its oxidation to dimethyl trisulfide. Future work should investigate the reaction pathways of sulfur AA present in milk protein as a precursor of sulfur compounds and their role in UP milk.

\section{CONCLUSIONS}

The flavor of milk processed by HTST, DSI-UP, or IND-UP was characterized by descriptive sensory and instrumental analyses. Heat treatments and fat level had distinct effects on sensory profiles of milk as demonstrated by higher overall aroma, cooked, and sulfur/ eggy flavors with UP milks compared with HTST milks. The DSI-UP and IND-UP differed from each other by sulfur/eggy, sweet aromatic, and cooked flavor intensities. The presence of Maillard reaction compounds $(2$ and 3-methylbutanal, furfural, 2-acetyl-1-pyrroline, benzaldehyde), methyl ketones (2-butanone, 2-hep- 
tanone), and sulfur-containing compounds (hydrogen sulfide, carbon disulfide, dimethyl sulfide, dimethyl trisulfide, methional) also distinguished UP milk from HTST, which were associated with the distinct cooked and sulfur/eggy flavors in UP milks. The major aroma active compounds were hydrogen sulfide, dimethyl trisulfide, and methional in DSI-UP and 2- and 3-meth- ylbutanal, furfural, 2-heptanone, 2-acetyl-1-pyrroline, 2-aminoacetophenone, benzaldehyde, dimethyl sulfide in IND-UP. These findings demonstrate differences in flavor formation by Maillard reaction and protein denaturation during thermal processing that affect the flavor quality of UP milks and distinct sensory and chemical differences between DSI-UP and IND-UP milks.

\section{Biplot (axes F1 and F2: $51 \%$ )}

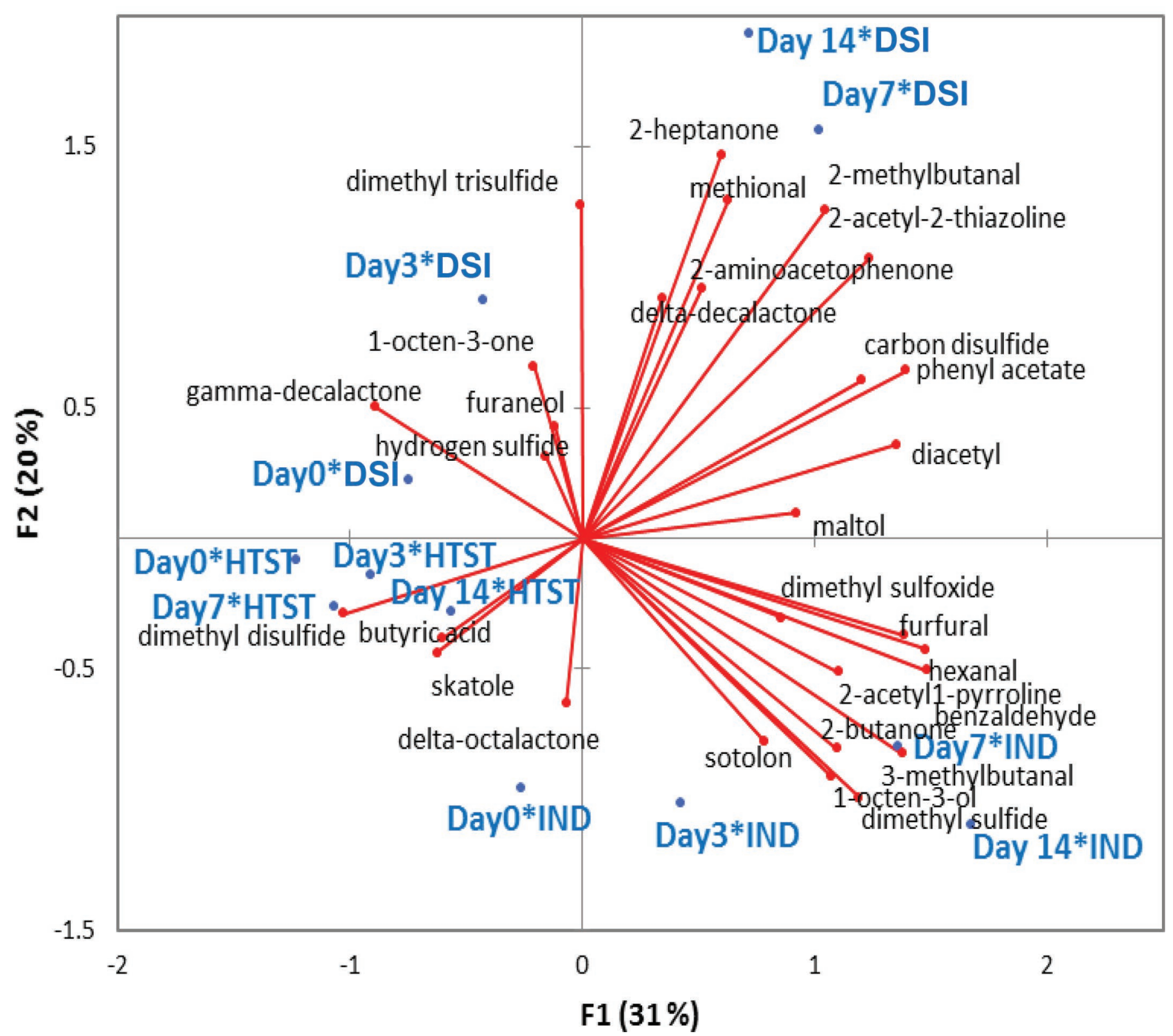

Figure 2. Principal component biplot for aroma active compound concentration of skim milks across $14 \mathrm{~d}$ of storage at $4^{\circ} \mathrm{C}$. DSI $=$ ultrapasteurization by direct steam injection; IND = ultra-pasteurization by indirect heating. Color version available online. 


\section{Biplot (axes F1 and F2: 57 \%)}

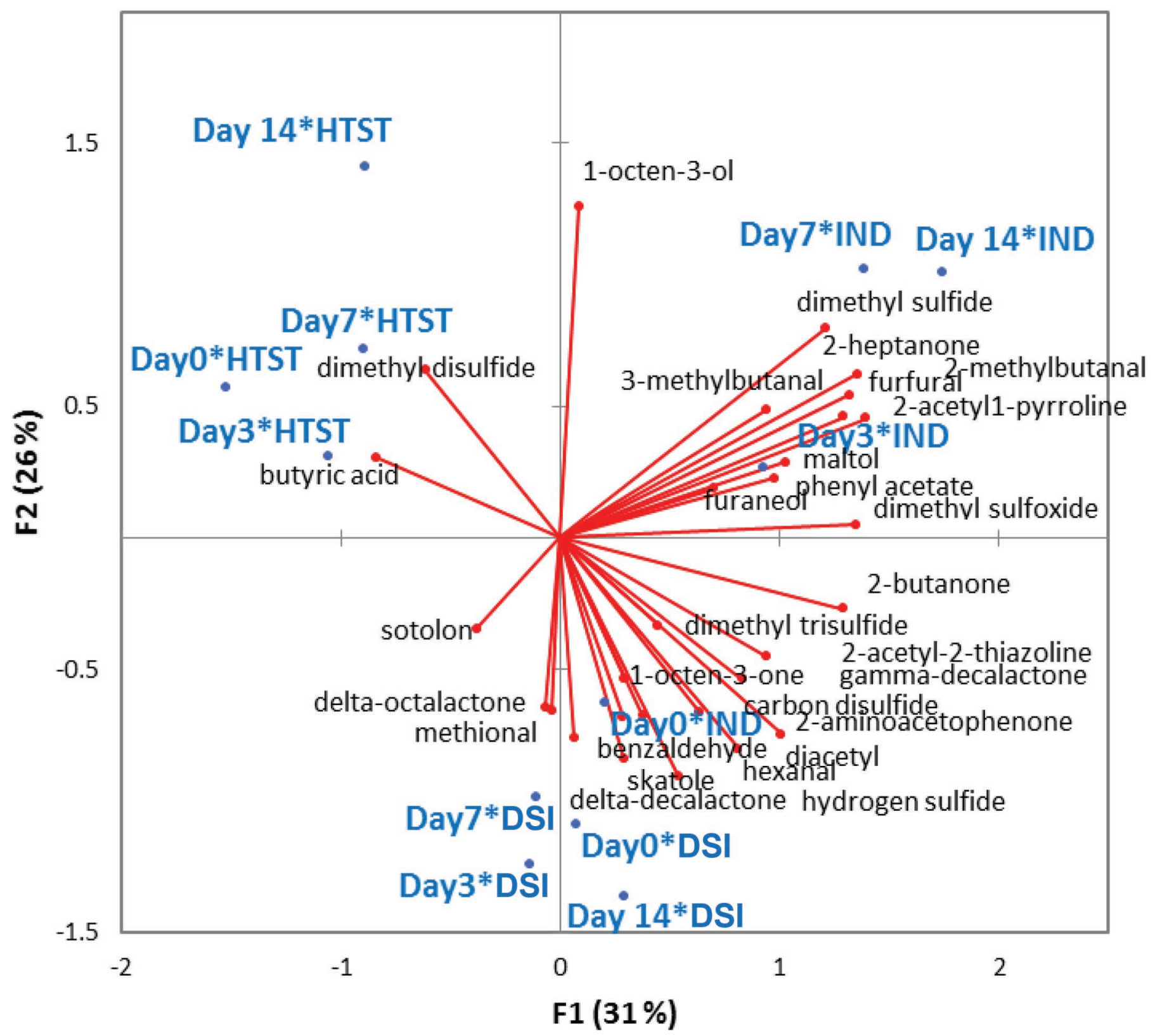

Figure 3. Principal component biplot for aroma active compound concentration of $2 \%$ milks across $14 \mathrm{~d}$ of storage at $4^{\circ} \mathrm{C}$. DSI $=$ ultrapasteurization by direct steam injection; IND = ultra-pasteurization by indirect heating. Color version available online.

\section{ACKNOWLEDGMENTS}

This study was supported in part by the National Dairy Council (Rosemont, IL). The use of tradenames does not imply endorsement or lack of endorsement by those not mentioned.

\section{REFERENCES}

Al-Attabi, Z., B. R. D'Arcy, and H. C. Deeth. 2009. Volatile sulphur compounds in UHT milk. Crit. Rev. Food Sci. Nutr. 49:28-47.

Al-Attabi, Z., B. R. D'Arcy, and H. C. Deeth. 2014. Volatile sulfur compounds in pasteurised and UHT milk during storage. Dairy Sci. Technol. 94:241-253. 
AOAC International. 2000. Official Methods of Analysis. 17th ed. AOAC International, Gaithersburg, MD.

Barbano, D. M., Y. Ma, and M. V. Santos. 2006. Influence of raw milk quality on fluid milk shelf life. J. Dairy Sci. 89:E15-E19.

Belitz, H.-D., W. Grosch, and P. Schieberle. 2009. Milk and dairy products. Pages 498-544 in Food Chemistry. 4th ed. Springer, Heidelberg, Germany.

BeMiller, J. N., and R. L. Whistler. 1996. Carbohydrates. Pages 157223 in Food Chemistry. O. R. Fennema, ed. Marcel Dekker Inc., New York, NY.

Boor, K. J. 2001. Fluid dairy product quality and safety: Looking to the future. J. Dairy Sci. 84:1-11.

Cadwallader, K. R., and T. K. Singh. 2009. Flavours and off-flavours in milk and dairy products. Pages 631-690 in Advanced Dairy Chemistry. Vol. 3: Lactose, Water, Salts and Minor Constituents. P. L. H. McSweeney and P. F. Fox, ed. Springer, New York, NY.

Calvo, M. M., and L. Hoz. 1992. Flavour of heated milks. A review. Int. Dairy J. 2:69-81.

Caplan, Z., and D. M. Barbano. 2013. Shelf life of pasteurized microfiltered milk containing $2 \%$ fat. J. Dairy Sci. 96:8035-8046.

Carunchia Whetstine, M. E., A. E. Croissant, and M. A. Drake. 2005 Characterization of dried whey protein concentrate and isolate flavor. J. Dairy Sci. 88:3826-3839.

Chapman, K. W., H. T. Lawless, and K. J. Boor. 2001. Quantitative descriptive analysis and principal component analysis for sensory characterization of ultrapasteurized milk. J. Dairy Sci. 84:12-20.

Christensen, K. R., and G. A. Reineccius. 1992. Gas chromatographic analysis of volatile sulfur compounds from heated milk using static headspace sampling. J. Dairy Sci. 75:2098-2104.

Colahan-Sederstrom, P. M., and D. G. Peterson. 2005. Inhibition of key aroma compound generated during ultrahigh-temperature processing of bovine milk via epicatechin addition. J. Agric. Food Chem. 53:398-402.

Contarini, G., and M. Povolo. 2002. Volatile fraction of milk: Comparison between purge and trap and solid phase microextraction techniques. J. Agric. Food Chem. 50:7350-7355.

Contarini, G., M. Povolo, R. Leardi, and P. M. Toppino. 1997. Influence of heat treatment on the volatile compounds of milk. J. Agric. Food Chem. 45:3171-3177.

Croissant, A. E., S. P. Washburn, L. L. Dean, and M. A. Drake. 2007. Chemical properties and consumer perception of fluid milk from conventional and pasture-based production systems. J. Dairy Sci. 90:4942-4953.

Czerny, M., and P. Schieberle. 2007. Influence of the polyethylene packaging on the adsorption of odour-active compounds from UHT-milk. Eur. Food Res. Technol. 225:215-223.

Datta, N., A. J. Elliott, M. L. Perkins, and H. C. Deeth. 2002. Ultrahigh-temperature (UHT) treatment of milk: Comparison of direct and indirect modes of heating. Aust. J. Dairy Technol. 57:211-227.

Di Marzo, L., P. Cree, and D. M. Barbano. 2016. Prediction of fat globule particle size in homogenized milk using Fourier transform mid-infrared spectra. J. Dairy Sci. 99:8549-8560.

Drake, M. A., S. C. McIngvale, K. R. Cadwallader, and G. V. Civille. 2001. Development of a descriptive sensory language for Cheddar cheese. J. Food Sci. 66:1422-1427.

Drake, M. A., R. E. Miracle, A. D. Caudle, and K. R. Cadwallader. 2007. Relating sensory and instrumental analysis. Pages $23-53$ in Sensory-Directed Flavor Analysis. R. T. Marsili, ed. CRC Press, Boca Raton, FL.

Drake, M. A., R. E. Miracle, and D. J. McMahon. 2010. Impact of fat reduction on flavor and flavor chemistry of Cheddar cheeses. J. Dairy Sci. 93:5069-5081.

Dwivedi, B. K., and R. G. Arnold. 1973. Chemistry of thiamine degradation in food products and model systems: A review. J. Agric. Food Chem. 21:54-60.

FDA (Food and Drug Administration). 2017. 21 CFR 131.3 Accessed Jun. 1, 2017. https://www.accessdata.fda.gov/scripts/cdrh/ cfdocs/cfcfr/CFRSearch.cfm?fr=131.3.

Glantz, S. A., and B. K. Slinker. 2001. Primer of Applied Regression \& Analysis of Variance. 2nd ed. McGraw-Hill Inc., New York, NY.
Grosch, W. 1982. Lipid degradation products and flavours. Pages 325-398 in Food Flavours. I. D. Morton and A. J. MacLeod, ed. Elsevier, Amsterdam, the Netherlands.

Grosch, W. 2001. Evaluation of the key odorants of foods by dilution experiments, aroma models and omission. Chem. Senses 26:533545 .

Hjelmeland, A., T. S. Collins, J. L. Miles, P. L. Wylie, A. E. Mitchell, and S. E. Ebeler. 2012. High throughput, sub ng/L analysis of haloanisoles in wines using HS-SPME with GC-Triple Quadrupole MS. Am. J. Enol. Vitic. 63:494-499.

Hoffmann, A., and A. Heiden. 2000. Determination of flavor and off flavor compounds in dairy products using Stir Bar Sorptive Extraction (SBSE) and Thermal Desorption GC/MSD/PFPD. App Note 5/2000, Gerstel, Mülheim an der Ruhr, Germany.

Hopfer, H., F. Jodari, F. Negre-Zakharov, P. L. Wulie, and S. E. Ebeler. 2016. HS-SPME-GC-MS/MS method for the rapid and sensitive quantitation of 2-Acetyl-1-pyrroline in single rice kernels. J. Agric. Food Chem. 64:4114-4120.

Hutton, J. T., and S. Patton. 1952. The origin of sulfhydryl groups in milk proteins and their contributions to 'cooked' flavor. J. Dairy Sci. 35:699-705.

Jeleń, H. H., M. Majcher, and M. Dziadas. 2012. Microextraction techniques in the analysis of food flavor compounds: A review. Anal. Chim. Acta 738:13-26.

Jeon, J. J., E. L. Thomas, and G. A. Reineccius. 1978. Production of volatile flavor compounds in ultrahigh-temperature processed milk during aseptic storage. J. Agric. Food Chem. 26:1183-1188.

Karagul-Yuceer, Y., M. A. Drake, and K. R. Cadwallader. 2001. Aroma-active components of nonfat dry milk. J. Agric. Food Chem. 49:2948-2953

Kaylegian, K. E., G. E. Houghton, J. M. Lynch, J. R. Fleming, and D. M. Barbano. 2006. Calibration of infrared milk analyzers: modified milk versus producer milk. J. Dairy Sci. 89:2817-2832.

Kokkinidou, S., and D. G. Peterson. 2014. Control of Maillard-type off-flavor development in ultrahigh temperature-processed bovine milk by phenolic chemistry. J. Agric. Food Chem. 62:8023-8033.

Kühn, J., T. Considine, and H. Singh. 2006. Interactions of milk proteins and volatile flavor compounds: implications in the development of protein foods. J. Food Sci. 71:72-82.

Kwon, T. Y., J. S. Park, and M. Y. Jung. 2013. Headspace-Solid Phase Microextraction-Gas Chromatography-Tandem Mass Spectrometry (HS-SPME-GC-MS) method for the determination of pyrazines in Perilla seed oils: Impact of roasting on the pyrazines in Perilla seed oils. J. Agric. Food Chem. 61:8514-8523.

Langen, J., C.-Y. Wnang, P. Slabizki, K. Wall, and H.-G. Schmarr. 2013. Quantitative analysis of $\gamma$ - and d-lactones in wines using gas chromatography with selective tandem mass spectrometric detection. Rapid Commum. Mass Spectrom. (Tokyo) 27:2751-2759.

Lee, A. P., D. M. Barbano, and M. A. Drake. 2017. The influence of ultra-pasteurization by indirect heating versus direct steam injection on skim and 2\% fat milks. J. Dairy Sci. 100:1688-1701.

Liem, D. G., D. P. Bolhuis, X. Hu, and R. S. J. Keast. 2016. Short communication: Influence of labeling on Australian and Chinese consumers' liking of milk with short (pasteurized) and long (UHT) shelf life. J. Dairy Sci. 99:1747-1754.

Lynch, J. M., D. M. Barbano, M. Schweisthal, and J. R. Fleming. 2006. Precalibration evaluation procedures for mid-Infrared milk analyzers. J. Dairy Sci. 89:2761-2774.

Lyster, R. L. J., T. C. Wyeth, A. G. Perkin, and H. Burton. 1971. Comparison of milks processed by the direct and indirect methods of ultra high temperature sterilization. J. Dairy Res. 38:403-408.

Marsili, R. T. 1999. SPME-MS-MVA as an electronic nose for the study of off-flavors in milk. J. Agric. Food Chem. 47:648-654.

Mattivi, F., L. Caputi, S. Carlin, T. Lanza, M. Minozzi, D. Nanni, L. Valenti, and U. Vrhovsek. 2011. Effective analysis of rotundone at below-threshold levels in red and white wines using solid-phase microextraction gas chromatography/tandem mass spectrometry. Rapid Commum. Mass Spectrom. (Tokyo) 25:483-488.

McCarthy, K. S., K. Lopetcharat, and M. A. Drake. 2017. Milk fat threshold determination and the effect of milk fat content on consumer preference for fluid milk. J. Dairy Sci. 100:1702-1711. 
Mehta, B. M. 2015. Chemical composition of milk and milk products. Pages 511-554 in Handbook of food chemistry. P. C. K. Cheung and B. M. Mehta, ed. Springer, Berlin, Germany.

Mehta, R. S. 1980. Milk processed at ultra-high-temperature, a review. J. Food Prot. 43:212-215.

Meilgaard, M. C., G. V. Civille, and B. T. Carr. 2007. Descriptive analysis techniques. Pages 173-186 in Sensory Evaluation Techniques. 4th ed. CRC Press, Boca Raton, FL.

Mestdagh, F., B. De Meulenaer, J. De Clippeleer, F. Devlieghere, and A. Huyghebaert. 2005. Protective influence of several packaging materials on light oxidation of milk. J. Dairy Sci. 88:499-510.

Misawa, N., D. M. Barbano, and M. A. Drake. 2016. Influence of casein as a percentage of true protein and protein level on color and texture of milks containing 1 and 2\% fat. J. Dairy Sci. 99:5284-5304.

Moid, L., P. Etievant, D. Langlois, J. Dekimpe, and F. Addeo. 1994. Detection of powerful odorants in heated milk by use of extract dilution sniffing analysis. J. Dairy Res. 61:385-394.

NIST (National Institute of Standards and Technology). 2014. NIST Wiley Registry: NIST Mass Spectral Library. 11th ed. Wiley, Hoboken, NJ.

Park, C. W., and M. A. Drake. 2016. Condensed milk storage and evaporation affect the flavor of nonfat dry milk. J. Dairy Sci. 99:9586-9597.

Perkins, M. L., and H. C. Deeth. 2001. A survey of Australian consumers' attitudes towards UHT milk. Aust. J. Dairy Technol. 56:28-34

Potineni, R. V., and D. G. Peterson. 2005. Influence of thermal processing conditions on flavor stability in fluid milk: benzaldehyde. J. Dairy Sci. 88:1-6.

Reineccius, G. A. 2006. Changes in food flavor due to processing Pages 103-137 in Flavor Chemistry and Technology. 2nd ed. CRC Press, Boca Raton, FL.

Scanlan, R. A., R. C. Lindsay, L. M. Libbey, and E. A. Day. 1968. Heat-induced volatile compounds in milk. J. Dairy Sci. 51:10011007.

Schamberger, G. P., and T. P. Labuza. 2007. Effect of green tea flavonoids on Maillard browning in UHT milk. Food Sci. Technol. 40:1410-1417.

Shibamoto, T., and S. Mihara. 1980. Flavor volatiles formed by heated milk. Pages 41-265 in The Analysis and Control of Less Desirable Flavors in Food and Beverages. G. Charalambous, ed. Academic Press, New York, NY.

Simon, M., A. P. Hansen, and C. T. Young. 2001. Effect of various dairy packaging materials on the headspace analysis of ultrapasteurized milk. J. Dairy Sci. 84:774-783.

Slabizki, P., C. Legrum, P. Wegmmann-Herr, C. Fischer, and H-G. Schmarr. 2016. Quantification of cork off-flavor compounds in nat- ural cork stoppers and wine by multidimensional gas chromatography mass spectrometry. Eur. Food Res. Technol. 242:977-986.

Smith, T. J., R. E. Campbell, Y. Jo, and M. A. Drake. 2016. Flavor and stability of milk proteins. J. Dairy Sci. 99:4325-4346.

Troise, A. D., A. Fiore, A. Colantuono, S. Kokkinidou, D. G. Peterson, and V. Fogliano. 2014. Effect of olive mill wastewater phenol compounds on reactive carbonyl species and Maillard reaction endproducts in ultrahigh temperature-treated milk. J. Agric. Food Chem. 62:10092-10100.

Urbach, G. 1993. Relations between cheese flavour and chemical composition. Int. Dairy J. 3:389-422.

Valero, E., M. Villamiel, B. Miralles, J. Sanz, and I. Martinez-Castro. 2001. Changes in flavours and volatile components during storage of whole and skimmed UHT milk. Food Chem. 72:51-58.

Van Boekel, M. A. J. S. 1998. Effect of heating on Maillard reactions in milk. Food Chem. 62:403-414.

Vandendool, H., and P. D. Kratz. 1963. A generalization of retention index system including linear temperature programmed gas-liquid partition chromatography. J. Chromatogr. 11:463-471.

Vazquez-Landaverde, P. A.. J. A. Torres, and M. C. Qian. 2006. Quantification of trace volatile sulfur compounds in milk by solid-phase microextraction and gas chromatography-pulsed flame photometric detection. J. Dairy Sci. 89:2919-2927.

Vazquez-Landaverde, P. A., G. Velazquez, J. A. Torres, and M. C. Qian. 2005. Quantitative determination of thermally derived offflavor compounds in milk using solid-phase micro extraction and gas chromatography. J. Dairy Sci. 88:3764-3772.

Vrhovsek, U., C. Lotti, D. Masuero, S. Carlin, G. Weingart, and F. Mattivi. 2014. Quantitative metabolic profiling of grape, apple and raspberry volatile compounds (VOCs) using a GC/MS/MS method. J. Chromatogr. B Analyt. Technol. Biomed. Life Sci. 966:132-139.

Walstra, P., T. J. Geurts, A. Noomen, A. Jellema, and M. A. J. S. van Boekel. 1999. Milk components. Pages 27-104 in Dairy Technology: Principles of Milk Properties and Processes. Marcel Dekker Inc., New York, NY.

Yeh, E. B., A. N. Schiano, Y. Jo, D. M. Barbano, and M. A. Drake. 2017. The effect of vitamin concentrates on the flavor of pasteurized fluid milk. J. Dairy Sci. 100:4335-4348.

Zhang, Y., X. Wang, L. Li, W. Li, F. Zhang, T. Du, and X. Chu. 2013. Simultaneous determination of 23 flavor additives in tobacco products using gas chromatography-triple quadrupole mass spectrometry. J. Chromatogr. A 1306:72-79. 